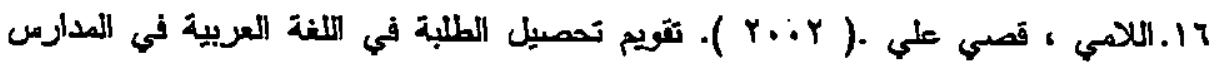

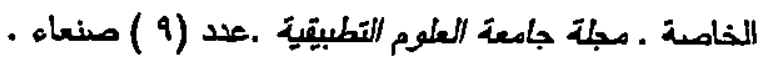

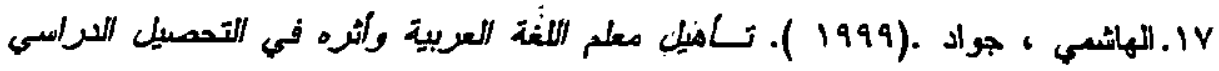
لالطبة.

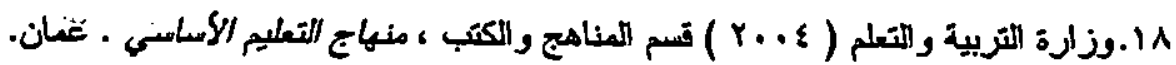

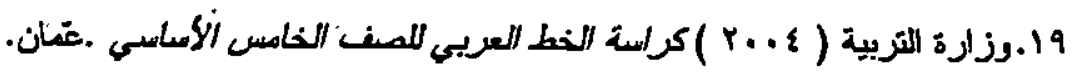

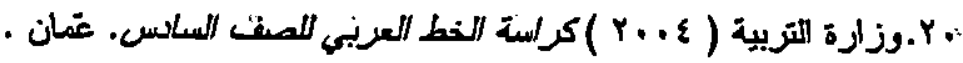

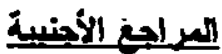

YI.Bloom, Benjamin.(19Y1). Handbook on formative and summative evaluation of student learning. New York: McGrow Hill .

Yr. Gall, M.D.( I99४), the use of formative evaluation. Educational Research.. $\{\cdot, 0$

.r. Holisti, L.A.(' 979$)$. Evaluation in Educational research. New York: McGrow. Schreiber, Paul. $\left(Y_{+}{ }^{i}\right)$. Testing and measurement in classroom, Boston: Houghton.

ห६. Terry, . A. Sara. ( $(१ १ \wedge)$. Evaluating Teachers Hand writing Educational. Research journal. \& , YrT. Washington D.C.

ro. Watson, Jack B.( 1999). Evaluating linguistic Tests. Charles MerrilI publishing Co. Ohio .

Y.Zenon, Allman M. $(Y \cdots)$ ). Teachers and Grading language Achievement: The Curriculum Journal ., , 17. 


\section{الميرلجع التعبية}

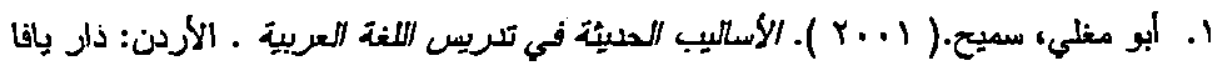

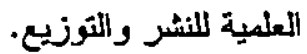

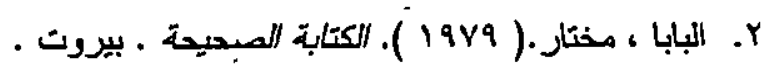

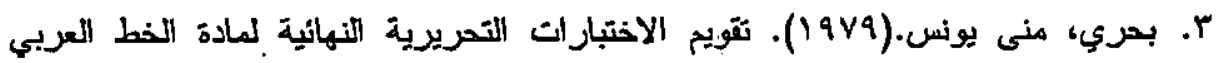

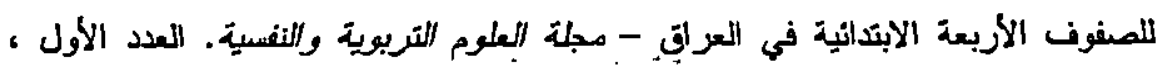
بغداد .

؛. بحري، منى يونس وعايف حبيب ؛( 1910 ). المنهج والكتاب المدرسي .مطبعة الحرية .

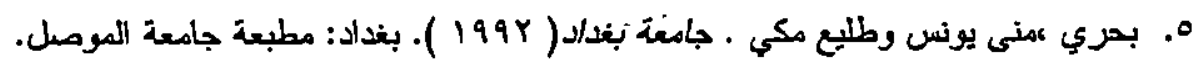

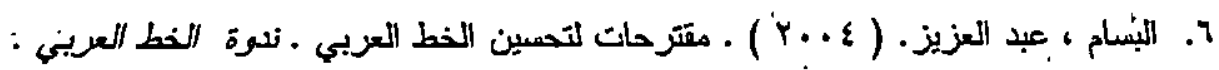

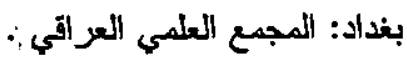
V. دمعة ، مجيد . ( •191). الضعف في التغبير الكتابي. أسبابه وعلاجه ـ مركز البحوث

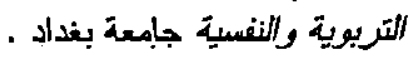

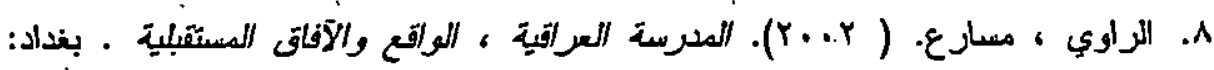
المجميع العلمي العراقي.

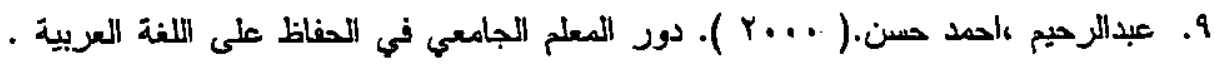
مركز البحوث التربوية والنفسية. جامعة بغداد . ماهن

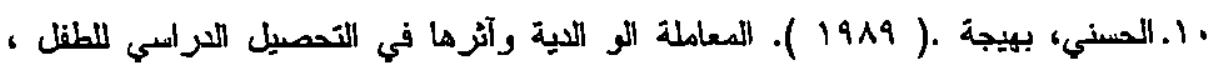

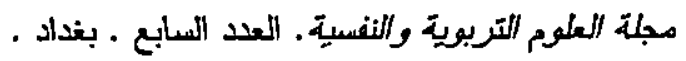

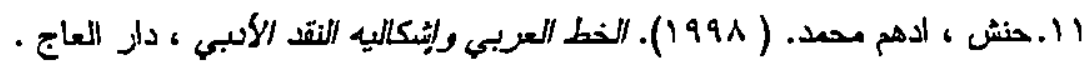

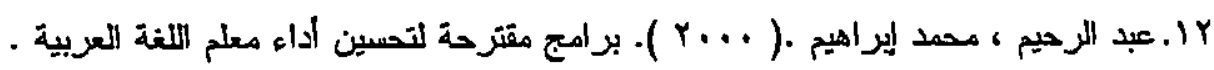
مجلة الضاد عدد (ع ) ، الخرطوم: جامعة الأحفاد.

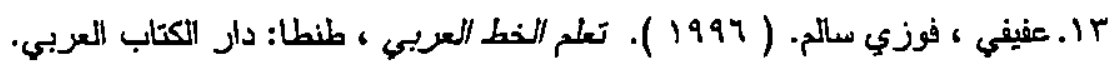

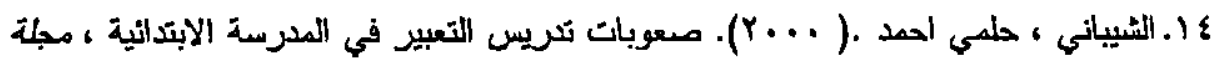

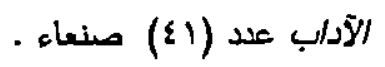

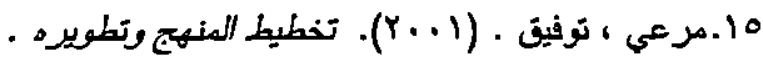


• لن استخدام أسلوب النظم في براسة. الثقويم التكويني في مجال الخط يساعد على مر امته بشكل

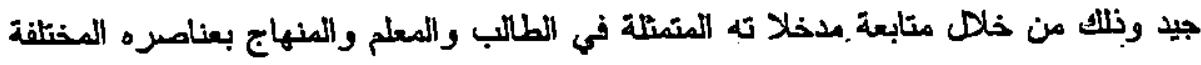

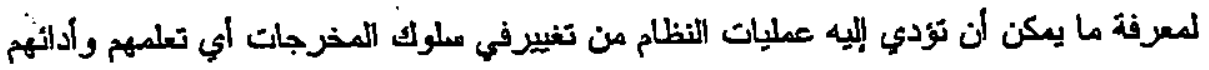

• لين أنماط التمقيم التكويني المستفلم في منظومة الخط العربي في التعليم الأساسي صحيحة

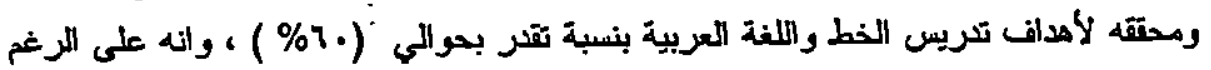

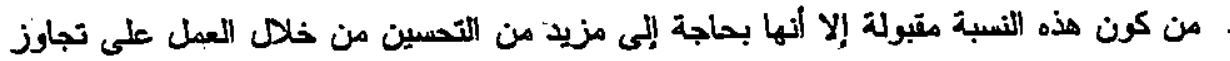

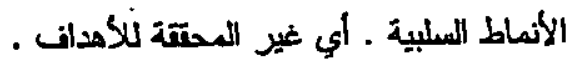

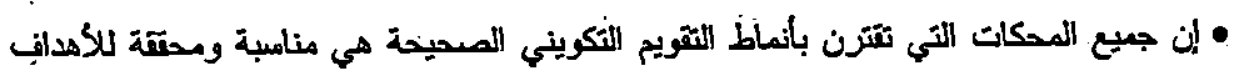
التربوية . • أن الطالب يكتسب معرفة ، ومهارات تنكير، ومهارات يدوية ، ونفسية ، من خلا أنماط

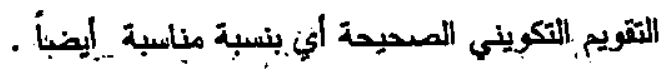
• لمن الطلب يكن أن يكتب تيما سامية متوعة توكد عليها الأهداث التربوية للغة العربية

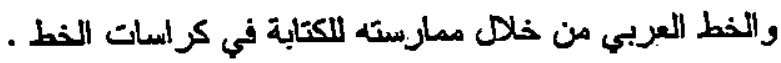

\section{توصيات اللار|سة :-}

• تريس مادة الخط العربي المعلمين أثثاء فترة الإعداد والخدمة في سيات نظمي .

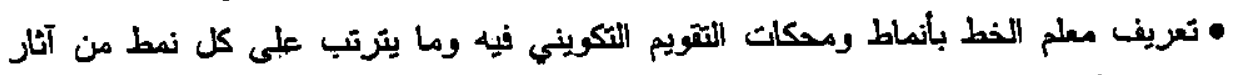

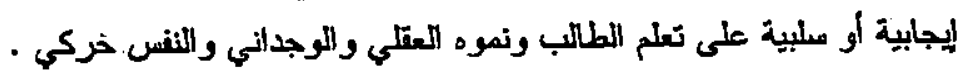

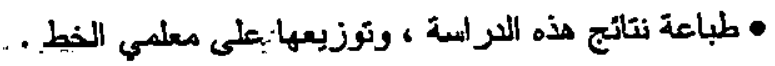
مترحات الار اسة :- ماسة • إعداد دراسة حول واقع التقويم التكويني في الكتابة في الصنوف الأريعة الأولي.

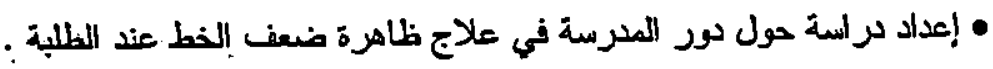




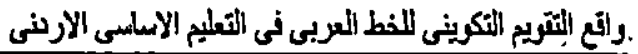

\begin{tabular}{|c|c|c|c|c|c|c|c|}
\hline.$\quad 1$ & Y & التناعة & $\varepsilon$ & & Y & لمثروة الطبيعية & $\varepsilon$ \\
\hline $1 Y$ & 1 & اللمجمع & & $\S$ & Y. & المجمرع & \\
\hline . & $-Y$ & تكامل اللخفمبة & .0 & & & المجال الثيني & $Y$ \\
\hline r & 1 & -العمورلية & -1 & & $v$ & الأيعان بالآخرة- & 1 \\
\hline & 1 & النجاح & r & & $\varepsilon$ & الأيعان بالجنة & Y \\
\hline “ & & الاجتهاد - & $r$ & & & - & \\
\hline$\Lambda$ & $\varepsilon$ & لالمجموع & & $r r$ & 11 & المجمبوع & \\
\hline$\sim$ & & ألمجال العلمي & 1 & & & المجال الاجتَاعي & $r$ \\
\hline & Y & حب العلم & 1 & & 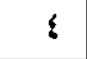 & الأخوة & 1 \\
\hline & & & & & r & حب الأبناء & $r$ \\
\hline$\varepsilon$ & $r$ & & & IY & 1 & المجموع & \\
\hline & $\$ 9$ & لالمجبرع الكلي & & & & & \\
\hline
\end{tabular}

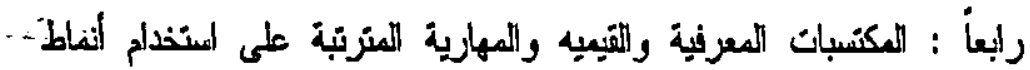

ومحكات التقويم التكريني بصورة منحيحة محقةَ للأهدان :-

- المعرفة بتراعد خط المرتعة .

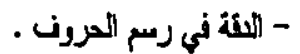

- العناية بنظاتة الكلمة .

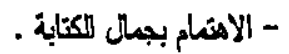

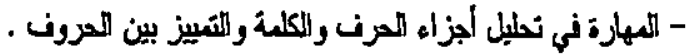

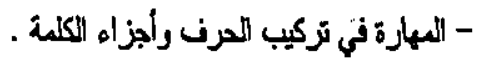

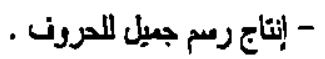

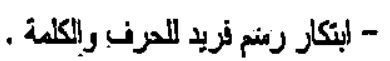

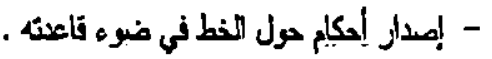

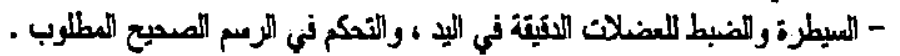




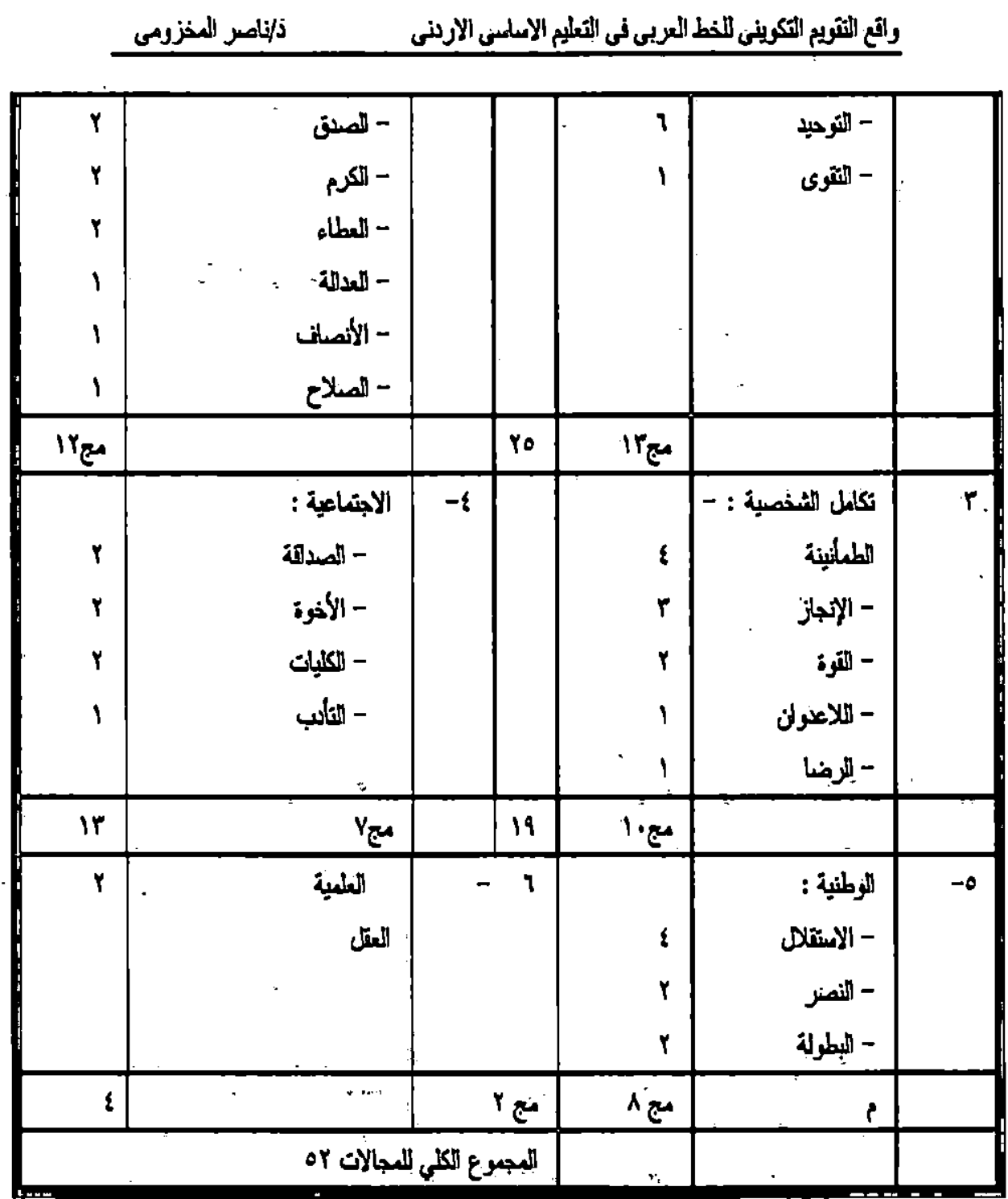

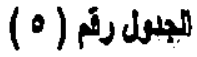

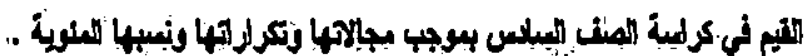

\begin{tabular}{|c|c|c|c|c|c|c|c|}
\hline$\%$ & التيكرل & ألمجال الأخلاهي & ? & $\%$ & التكرار & العجال الأمتملاين & 1 \\
\hline & r & للصبر & 1 & & $\gamma$ & J & 1 \\
\hline & 1 & إلعدالة & $r$ & & 7 & النع & $\bar{Y}$ \\
\hline & 1 & للعاواة & $r$ & & - & العبل & $r$ \\
\hline
\end{tabular}




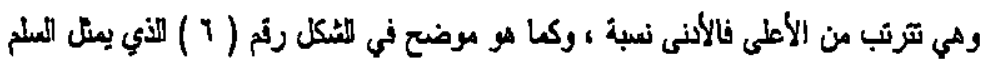

(1) Jets

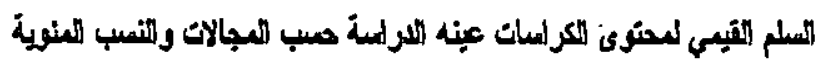

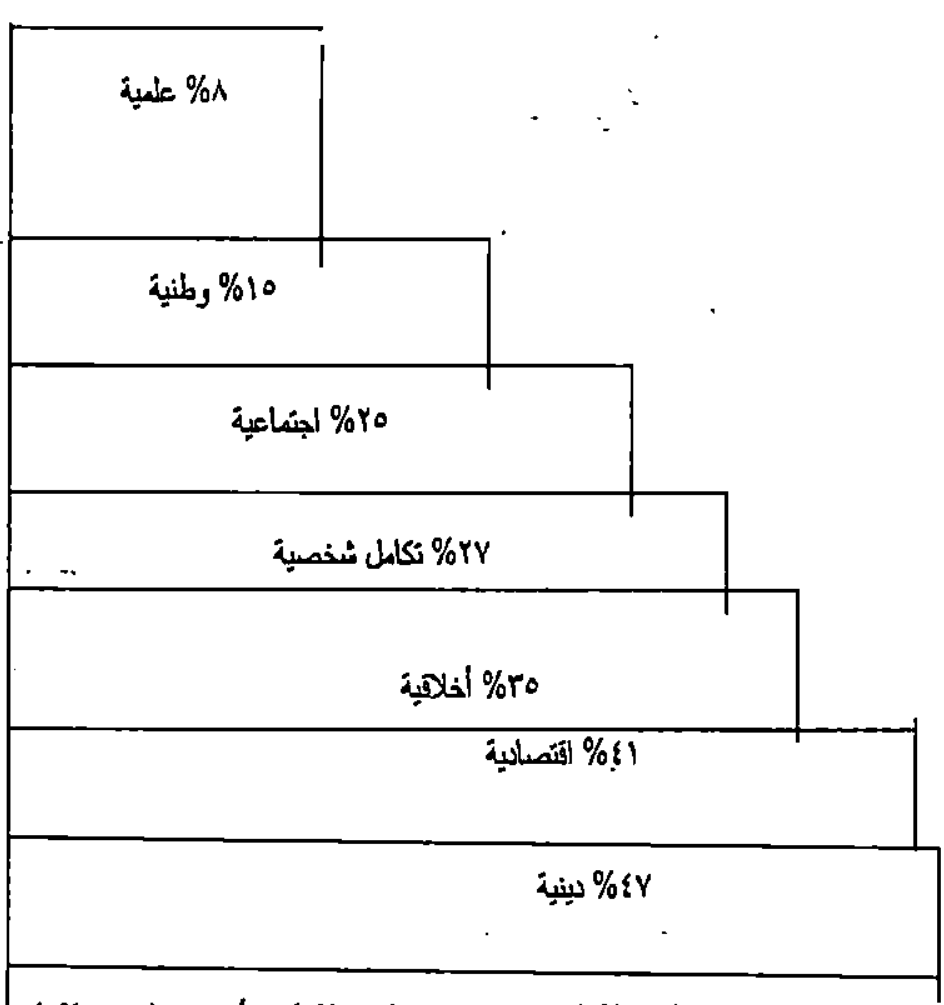

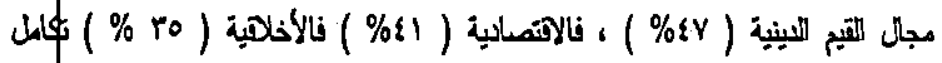

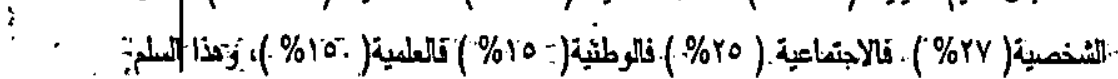

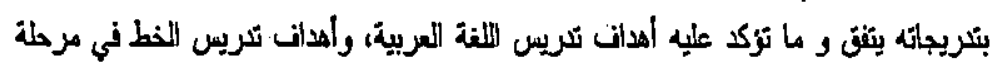

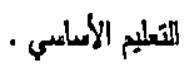

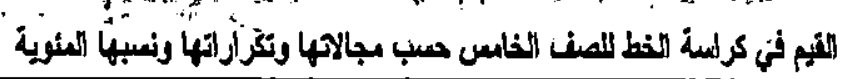

\begin{tabular}{|c|c|c|c|c|c|c|}
\hline & & & $\%$ & التكر الر & المجال & ? \\
\hline$r$ & - الأفلاقية : المعاعدة & $r$ & & 1 & - الاينية : الايمان بالبد & $i$ \\
\hline
\end{tabular}


كما إن نسب اهنمام المعلمين بمراعاتها. في تقويمهم التكويني اللخط مقبولة ، والثبكل رقم (0)

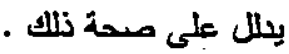

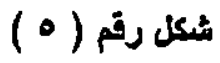

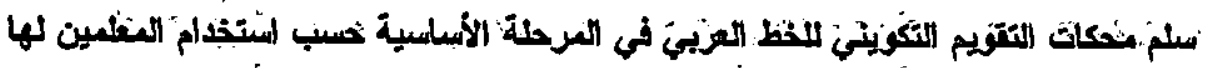
في كراسعات الاعينة

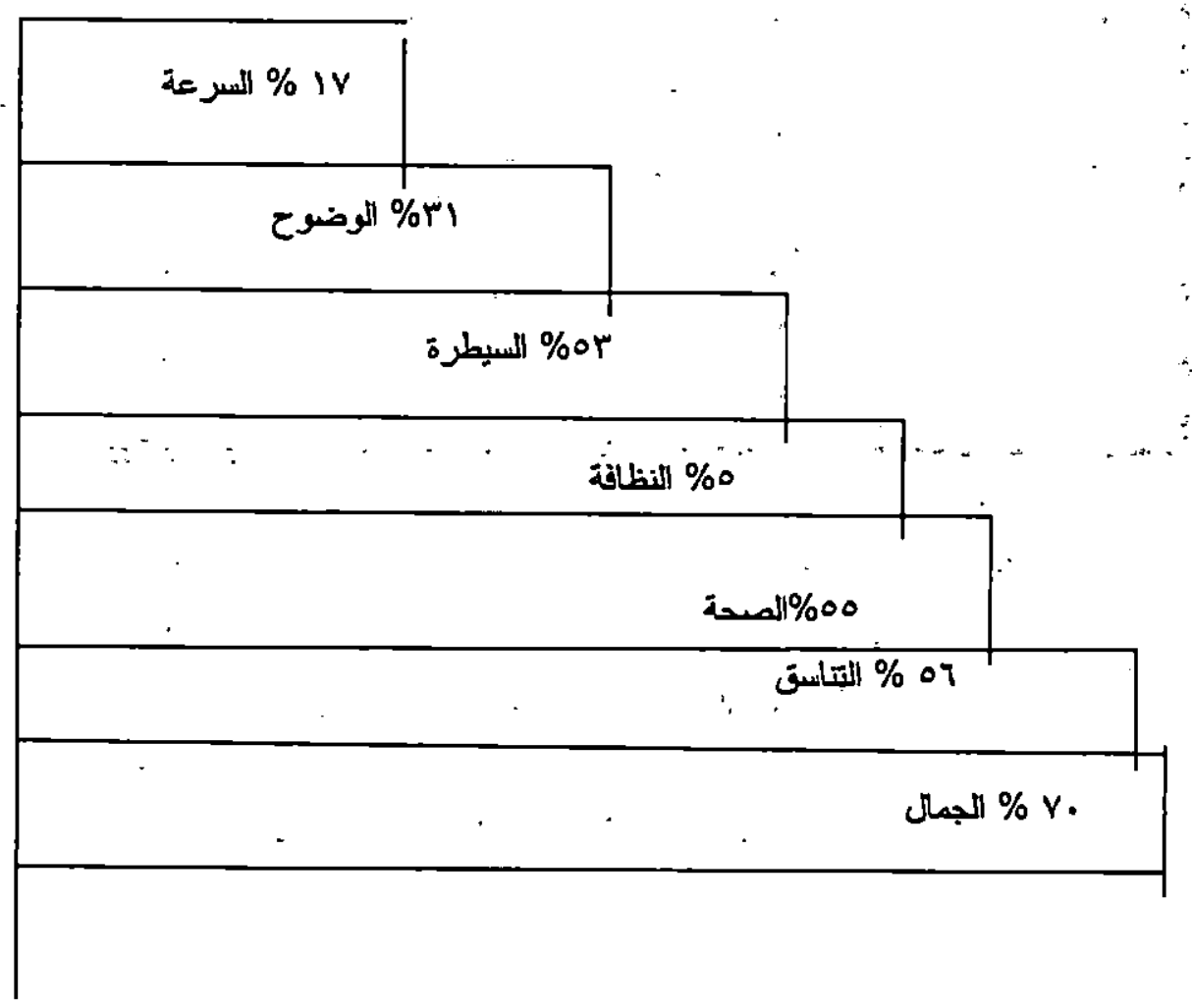

ثالثان : الاتيم في مدنوى كراسات الخط

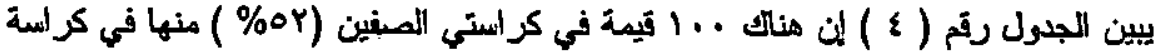
الصف الخامس و ( 
ثانباً : محكات الأثاط التثريعية التكوينية للخط :-

الجدول رقم (r)

متوسطات نسبه محكات الثتويم التكويني في الكراسات عينه العر اسنة

\begin{tabular}{|c|c|c|c|c|}
\hline متروسطات الثنسب & الصف العاسع % & الصف الخامس \% & المحكات & p \\
\hline -0 & $\varepsilon \wedge$ & 7 & الصحة & .1 \\
\hline 07 & $\varepsilon$. & r & التناسق &.$Y$ \\
\hline v. & 94 & $\mathrm{~V} \varepsilon$ & الجمال &.$r$ \\
\hline or & 0. & 00 & السيطرة &.$\varepsilon$ \\
\hline r) & $\varepsilon$. & YY & الوضوح & .0 \\
\hline 07 & $\pi$ & 01 & النظافة & .7 \\
\hline iv & 19 & $1 \varepsilon$ & اللسرعة &.$V$ \\
\hline
\end{tabular}

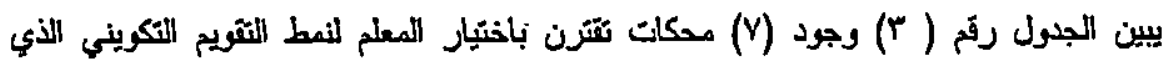

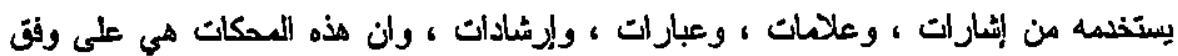

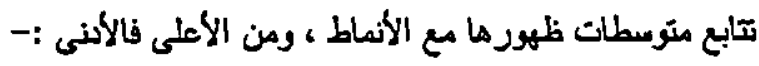

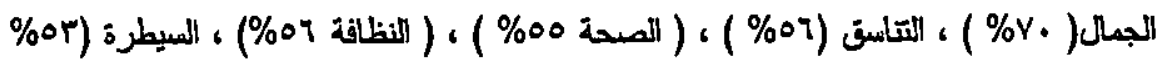

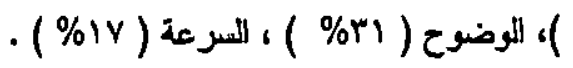
لمن هذه المحكات صحيحة وتنثق مع ما توكد عليه أهدانف تكريس الخط في التعليم الأساسي . 
- إنة ( 'في الصف الخامس ، وهذا يناسب صفه ومرحلته النهائية ، ويحقت أهداف تريس الخط إلان أن )

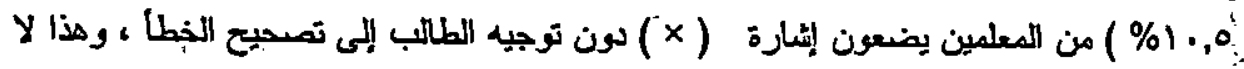

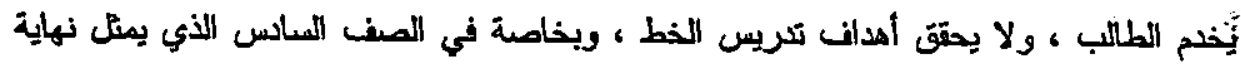
هُمْرحلة تعليمية أنساسية

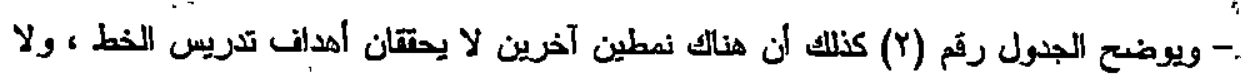
يفيد الطلب مِنها شيئا في الخط ، وهما نمط كتابة كلمة لوحظ مع التاريخ على الدرم المحفوظ ": ونمط ترك هذا المرس بلا تصحيح وينسبة ( ع\% ) ، و(r\%) لكل منهما في الصفين وعلى

و اللشكل رقم (ع) يوضت أنماط الثقويم التكويني في كر السات المعينة حسب نسبها المنوية .

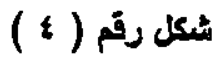

سلم أنعاط المتويم التكوينه في كراسات العزينة حسب نسبها الشوية

\begin{tabular}{|c|c|c|c|c|c|}
\hline & $\ldots$ & $\ldots$ \\
\hline \\
\hline
\end{tabular}




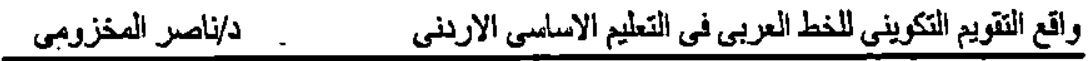

\begin{tabular}{|c|c|c|c|c|c|c|c|}
\hline$\{r, 0$ & YIq & $r q$ & 91 & 01 & $|Y|$ & والتوجيه. خط تحت الخطا مع & 1 \\
\hline ir & $Y$. & $.1 \varepsilon$ & m & 9 & $r \varepsilon$ & تشفير علمات : اجتهاد & r \\
\hline 11 & of & IY & r & 9 & זוץ & حسب علد الأخطاء. & $r$ \\
\hline $1 \leqslant, 0$ & ni & 17 & \&1 & $1 \varepsilon$ & $r$. & 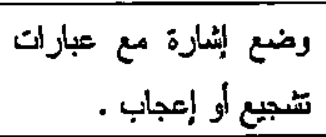 & 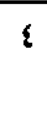 \\
\hline $1 ., 0$ & 01 & 1. & Yq & 11 & YY & توجيه. & - \\
\hline$\varepsilon$ & YY & 0 & ir & $\varepsilon$ & 1. & كتابة كلمة ( لوحظ مع & 1 \\
\hline$r$ & iv & $\xi$ & $\wedge$ & $\varepsilon$ & 9 & 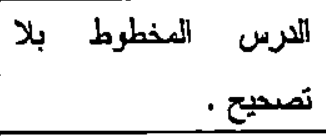 & $\mathrm{v}$ \\
\hline $1 \ldots$ & o.. & $1 \ldots$ & ro. & 1.. & Yo. & & \\
\hline
\end{tabular}

\section{يبين الجدول رقم (Y) هذا الواثق من حيث أن :}

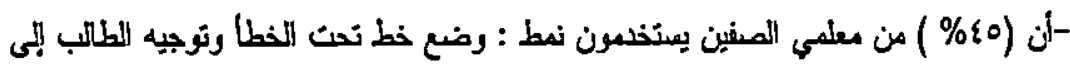

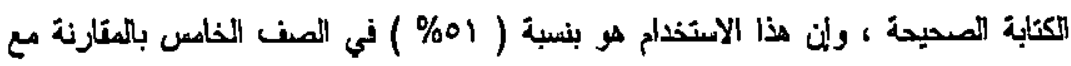

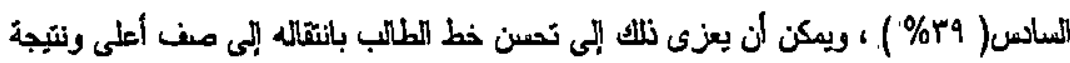

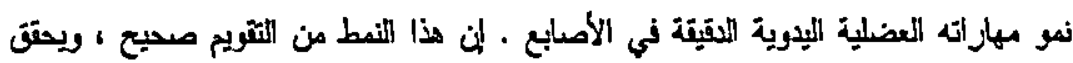
أهدات تعليم الخط . تمباته العفلية

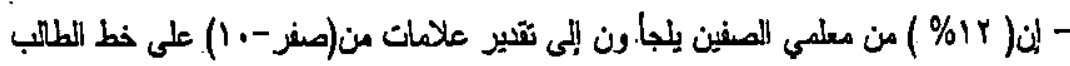

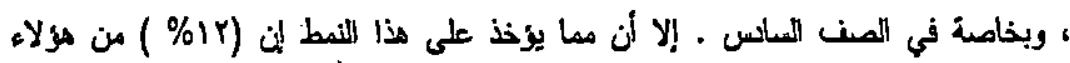
المعلمين يترون العلامة باجتهادهم اللثخصي دون تحليد الخطا للطالب، ونسبة مالثئه منهم

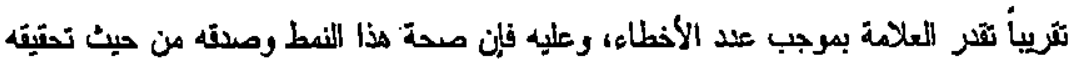

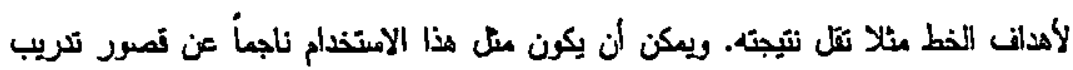

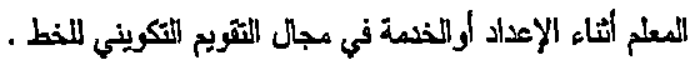


• - كتابه كلمة لوحظ مع اللتاريخ

• إهمل تصحيح الصفحات المكتربة .

أما محكات الأثماط التي توصل إليها الباحث فهي :

• الصحة : محة رسم الحرون بموجب خط الرقعة .

• • التناسق : ثناينق رسم الحرون على السطر الأفقى .

• الجمال : جمال الخط نسبياً .

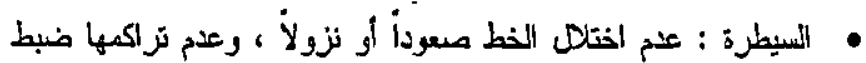

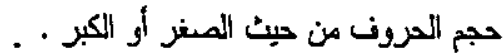

$$
\begin{aligned}
& \text { • الوضوح : فهز القارى للمكتوب . }
\end{aligned}
$$

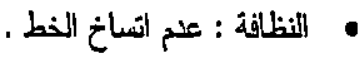

$$
\begin{aligned}
& \text { • المبر عة : إكمال خط المطلوب ضمن الحصة . · }
\end{aligned}
$$

وتام الباحث بتحليل كراسة الصف الخامس والساس تخليلا بعدياً لمعرفة ما بتضمنه محتواهما من سلم قيمي .وعزض الباحث نتائج تحليل المحتوى على ثلاثة خبراء في اللغنة

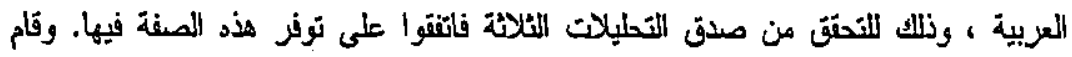

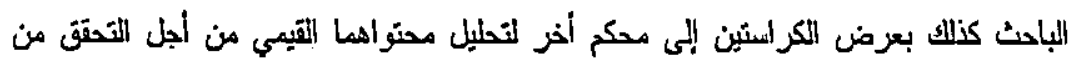

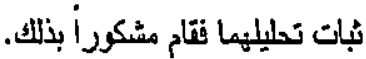

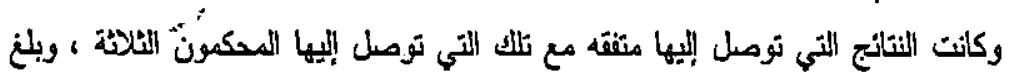
معامل الاتفاق على ذلك بموجب هغادلة Pearson ( 197 (. ) .

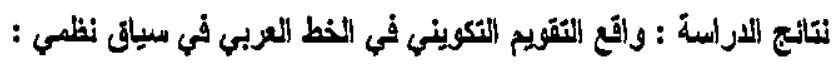

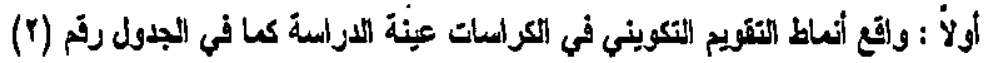

$$
\text { الجدول رقم (r) }
$$

واققع أنماط التقويم التكويني في الكراسات عينه الإِراسة حسب تكراراتها ونسبها المنوينة

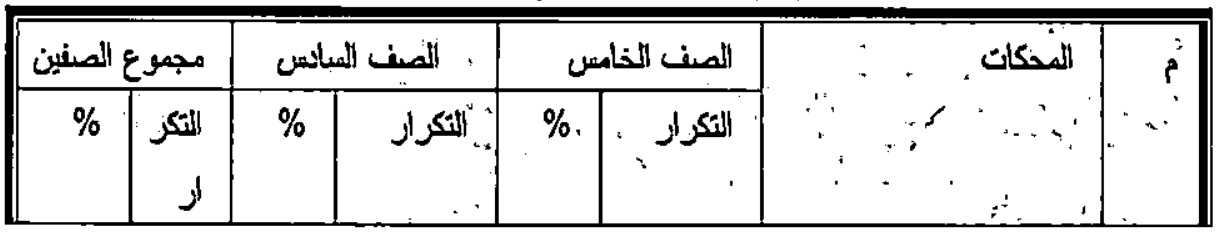


بموجبه يخرج الباحث بتصنيف للمعلومات التي حلها، ويمكن للباحثين الآخرين الاعتماد عليه في بحوثهم التحليلية اللاحقة .

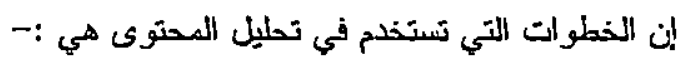

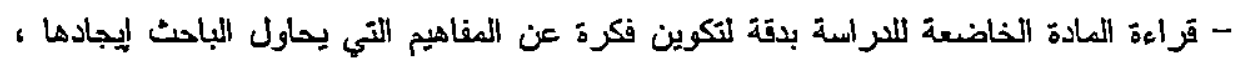

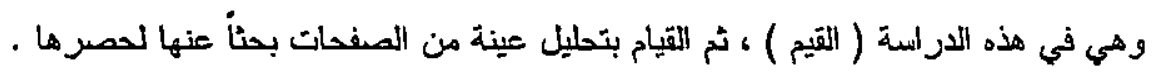

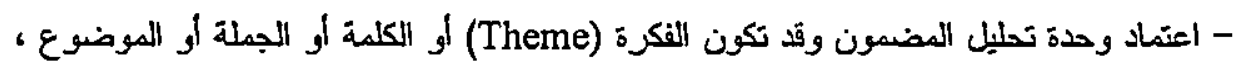

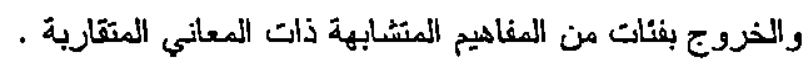

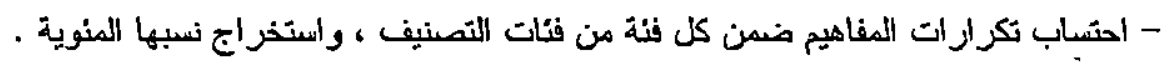

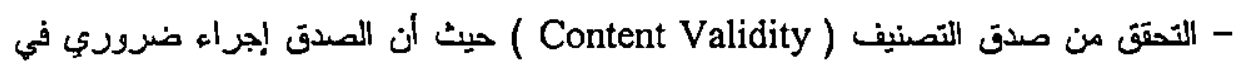

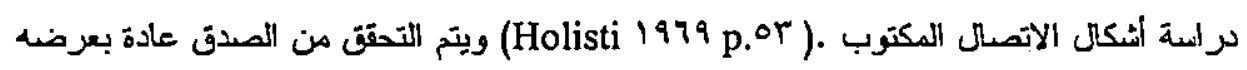

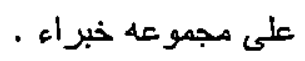

- التحقت من ثبات التحليل ( Reliability ) بإعادة الباحث لتحليل عينة من الصفحات بعد فترة

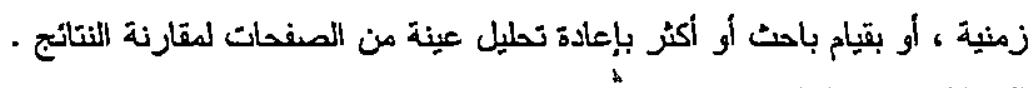

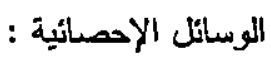
التكرار الت : التمان

لحساب مجموع مر ات استخدام كل نمط ومحك أو قيمة في الكر اسات. النسبة المئوية :

- نتحليد نسبة استخدام النمط أو المحك إلى المجموع الكلي لكل منهما.

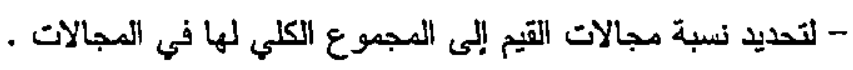

\section{ثالثاً : التحيل الاسنطلاعي لعينة أولية}

من أجل تحديد أنماط ومدكات التقويم التكويني الدستخدم في الكراسات قام الباحث بتحليل عينه

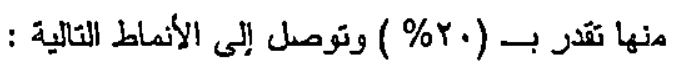

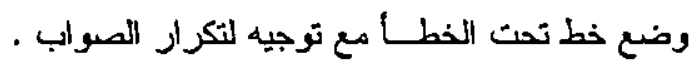

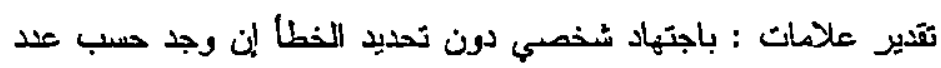
الأخطاء .

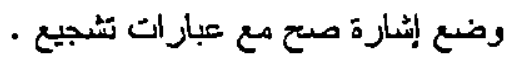

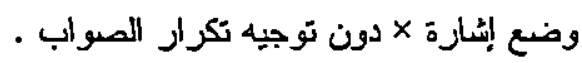




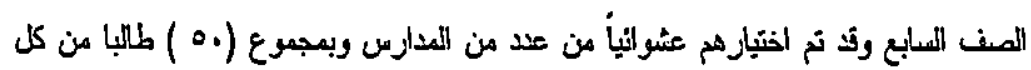

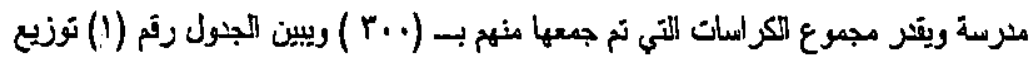

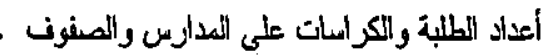

جدول رقم (1)

توزيع أعداد الطلبة والكراسات على المدارس والصنون

\begin{tabular}{|c|c|c|c|}
\hline علد الطلبة / كراسات صف & عدد الطلبة/ كراسعات صف & المعرسة & م \\
\hline Yo & ro & أبو بكر الثانوية & .1 \\
\hline Yo & ro & أبو علندا &.$Y$ \\
\hline ro & ro & أم الحبرلن & $r$ \\
\hline Yo & Yo & إسكان المالية & . \\
\hline Yo & Yo & الليادودة & .0 \\
\hline Yo & Yo & سحاب & .1 \\
\hline$=\quad r_{0}$ & Yo & محمد بن القاسم &.$v$ \\
\hline ro & Yo & صلاح اللدين &.$\wedge$ \\
\hline ro & Yo & محد إقبّان & .9 \\
\hline ro & Yo & حطين & 1. \\
\hline \begin{tabular}{l|l}
$0 .$. & Yo.
\end{tabular} & Yo. & & المجد \\
\hline
\end{tabular}

ثانياً : أداة المراسة :

أسلوب تحلِل المحتوى :

ويعرن في البحث الحالّي باعتباره أداة من أدوات البحث التي تستخدم في تحليل النصوص المدونة كالكتب المنرسية حيث يتم الاعتماد على طرق متعندة في نلك منها :

لمن الاعتماد على تصانيف جاهزة لتمليل المادة المكتربة ، أو بناء تمنيف للتصليل، أو القيام

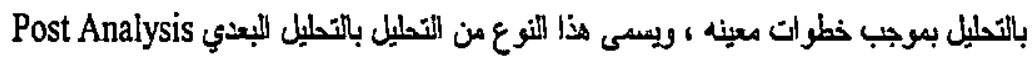


- إعطاء قيمة للأشياء .

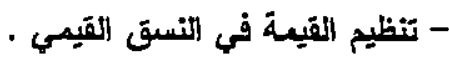

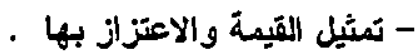

أما كلير ( Keller, 19Y ) فتد لاحظ الباحث أنه صنف الأهداف التربوية في المجال النفس

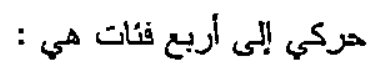
- مهارات العركات الجسمية الكبرى . - المهار ات الحركية دقيقة التتاست كرسم الحروف . - مهارات التو اصل اللفظية . - مهارات التوأمل غير اللفظية كرسم الحروف . إن ما سبق ذكره من تصاتيف للتقويم التكويني ساعد الباحث في الإجابة عن الأسئلة:

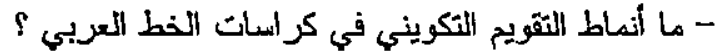
- وما محكاته ؟ - وما الأذي يكتببه الطالب من هذا الثتويم :معرفة ،قيم ، مهارات ؟ أما (المحلك) فهو في اللغة العربية يرجع البى تقليد أتبعة العرب وهو الستخدام قطع الأحجار

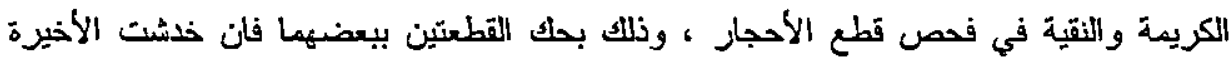

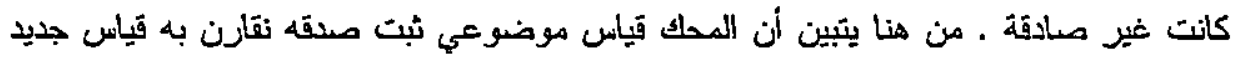

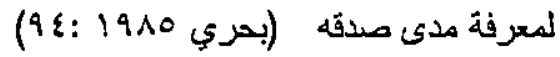
ويؤكد هولستي( Holisti 1979,04) على أن المعلم في استخدامه لانماط الثقويم التكويني

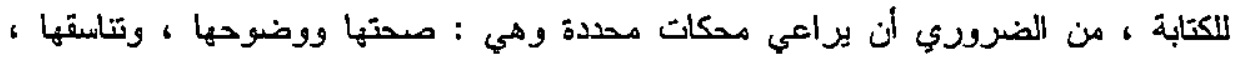
وسيطرة الطالب على حروفها ضمن المدى الزمني المخصص لها.وان الباحث الذي يحاول دراسة مثل هذا التقويم عليه التحتق من صدق ولئ ونبات أداته.

$$
\begin{aligned}
& \text { الخطوات التي تم اتباعها للتعرف على واقع التقويخ التكويني في الخط: } \\
& \text { أولا: تحديد العينة: }
\end{aligned}
$$

تم الحصول على عئية من كراسات الخط المكتملة التصحيح من عينه من الطلبة الذين أكملوا

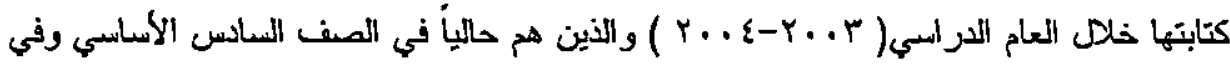


- التمتويم الوصفي النوعي مثل : ضعيف ، جيد ، جيد جدأ ، مثتاز ، أحسنت .

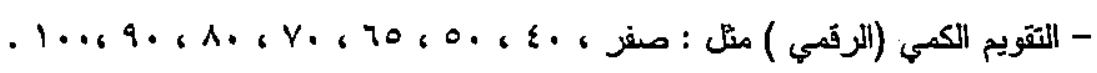

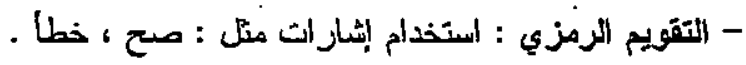

تصنيف تشيربر ( SchreiberY..l p.T ) للثتويم التكويني في المواد الاجتماعية الذي يعتمد

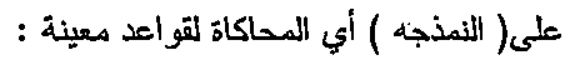
التكرار : ويساعد على تذكر القاعدة . الترتيب : الأي يساعد على ترثيب النموذج حسب تسلسل أو سياق معين .

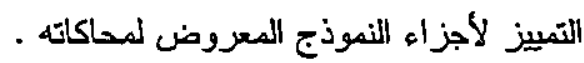

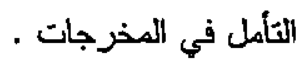
وضع أحكام معنوية .

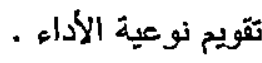

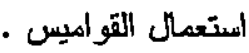

Bloom Taxonomy of Educational : تصنيف عام اللتقويم للتبرف على العمليات العقلية : Objectives 1. المعرفة : معرفة أشياء خاصة معينة ، معرفة طرق ووسائل معالجة أشياء خاصة، معرفة ، معاء

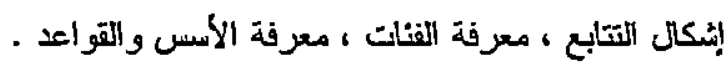

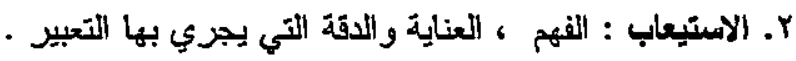

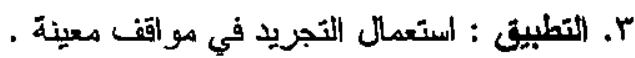
ع. التحليل : تحليل العناصر ، تحليل العلاقات المتبادلة .

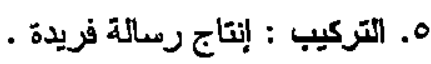
1. التقويم : إصدار أحكام في ضوبء أدلة .

هذا وهناك تصانيف عامة أخرى للكافت الوجدانية لـ (Krathwool) وللنفس حركية - (Keller)

هذا وقد اختار الباحث أيضأ كراث هول أحد تصانيف المجال الوجداني وقد قَسم (krathwool)

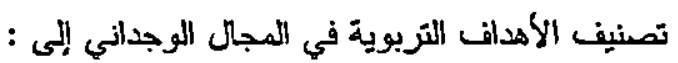

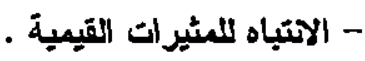

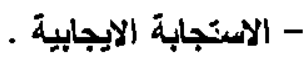


ثالثاً : يكتب المعلم الكلمات المفردة على السبورة ، ويناقش الطلبة في كيفية رسم الحروف ، وإذا لم يتمكن المعلم من ذلك يكتفي بلفت نظر الطلبة إلمى هذه الحروف والألفاط المكتوبة في الكراسة

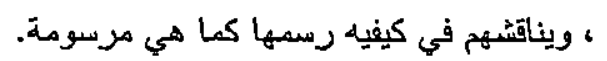

رابعأ : يبدأ الطلبة في كتابة الألناظ المفردة ليتقن كتابتها ، ومن ثم ينيقلون الئى كتابة النموذج من أسفل إلى أعلى ، ويلاحظ المعلم كتابتهم ، ويتوم بارشادهم كان يقول لاحدهم:-

$$
\text { كتبر كتابتك قليذا لو كثيرًا . }
$$

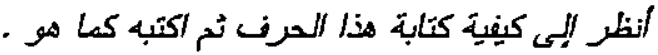

$$
\begin{aligned}
& \text { وحد المسافات بين الكمات . } \\
& \text { لاحظ نظام الكتابة على السطر - }
\end{aligned}
$$

خامسأ : لإذا وجد المعلم خطا شائعأ في رسم بعض الحروف ، يناقش الطلية في كتابته، ويعل على ايضاحه ، وكيفيه كتابته بصورة صحيحة . سادأ : يصحح المعلم الكراسات بلدقه معيناً الخطأ في شكل المرف ورسمه ، ويصحمه اللطلب وكلب

إن وصف طريقة التّريس والتوسائل التعليمية ساعد الباحث على الإجابة عن المؤالين : ما أنماط الثقويم التي يمكن استخدامها أثناء التكريس ؟ ما المحكات التي يمكن استخدمها لتثويم تقييمٍ المعلم ؟

$$
\text { العنصر الر ابع : التقويم :- }
$$

يؤكد جونسون (Johnson . 199^.plr.p إن مهارات التقويم التكويني تدور حول محور مهم هو أنظمة تضيفها بما يراعي منتوى تفكير الطالب ، وتحصيله ، و الأهداف التربوية وقد وضع

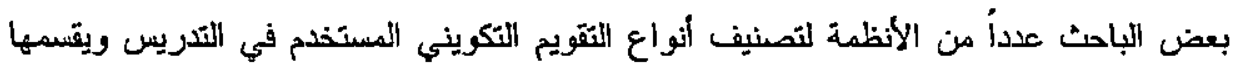

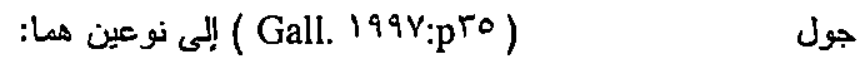

- أنظمة عامة يصنف الثقويم بموجبها دون اعتبار لمادة الدروس ومرحلة الدرامسة - أنظمة خاصة بمادة درس محدد ، ولمرحلة دراسية محدده . كأن يكون النظام خاصا باللغة اعنة

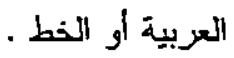

وفيما يلي نماذج لتلك الأنظمة :- تضيف جمعية معلمي المواد الاجتماعية في مدينة نيويورك لأنماط الثقويم التكويني 
وتؤكد الكراسة على أهمية حُسن الخط للطالب. وبان التقويم يكون تكوينيا مستمرا طولال الحصة|لأسبو عية :- وتئكية

بتوجيه الطلية إلى الطريقة الصحيحة في رسم الحروف وفق خط الرقعة ومتابعه ذلك

لإتقانها

بتشجيع الطلبة الموهوبين في الخط .

بروس الخط في الكراسة بموجب صفداتها :-

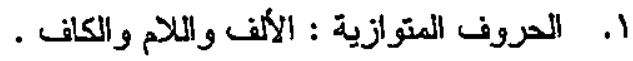

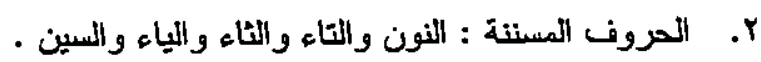

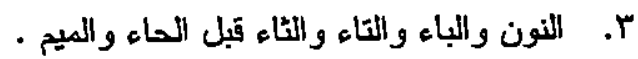

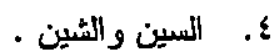

ه. الصاد و الفناد .

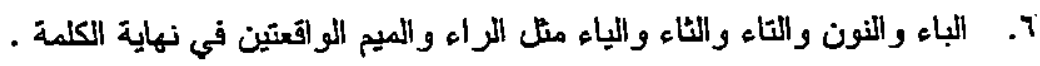

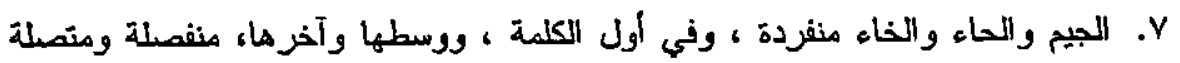

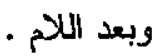

1. الكاف الأخيرة واللام الأخيرة .

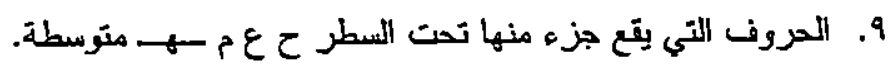

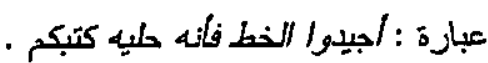

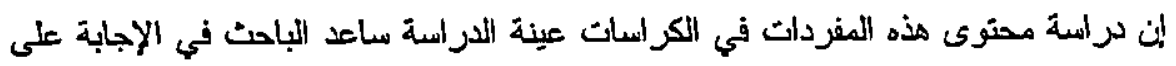

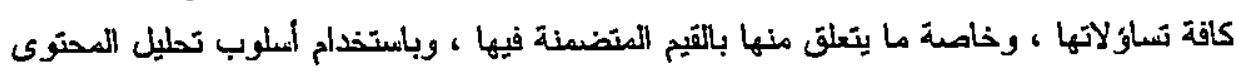
، وكما يتضح لاحقاً .

الإجراء الرابع : وصف طريقة تدريس الخط في الصفين الخامس والسادس (الأسة (الأشططة):

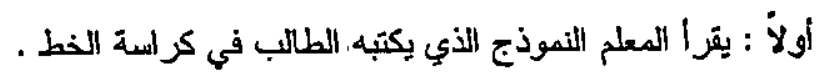

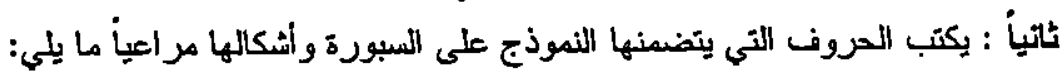

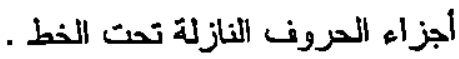

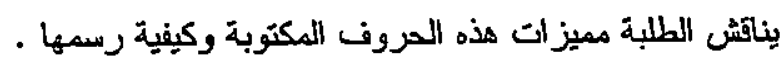


مقدمة للزملاء المعلمين توضيح كون الكراسة منضمنة قواعد كتابة الحروف التي نص عليها منهاج المف الخامس بخط الرقعة ، وبان لكل حرن صفحتين خصصت أولاهما لتريب

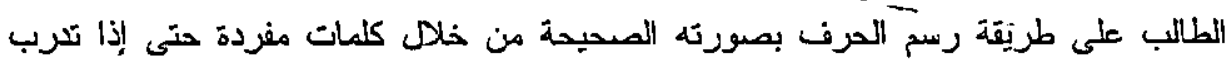

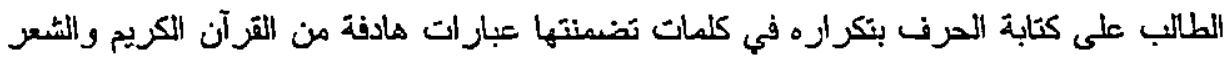

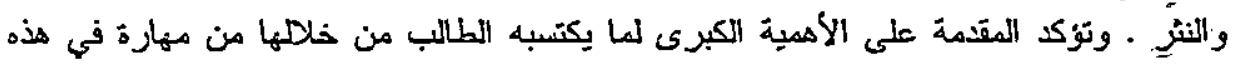

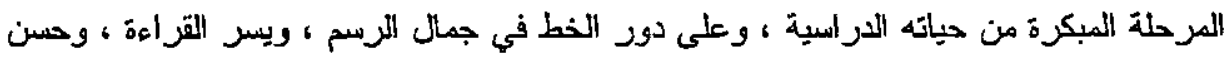

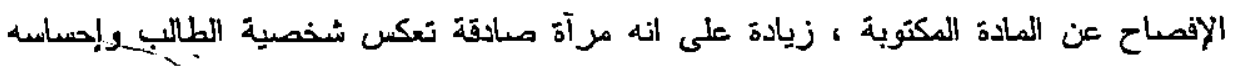

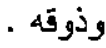

التعريف بخط الرقعة وبطريقة تدريس المعلم للكرائة ، وتقويمه لخط الطالب فيها .

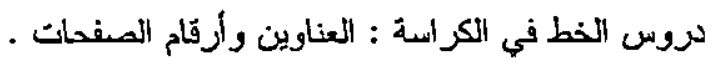

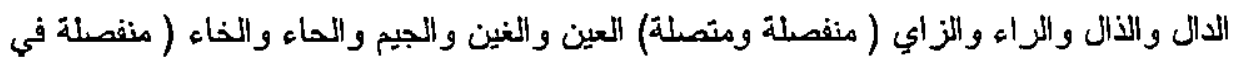

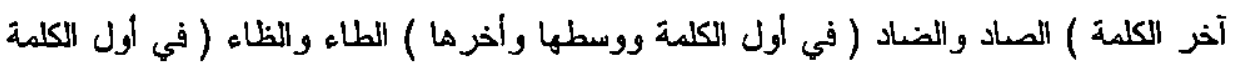

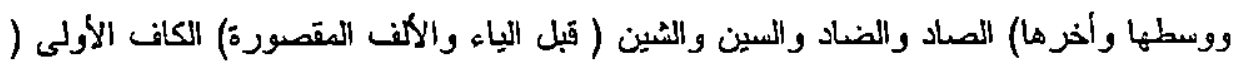

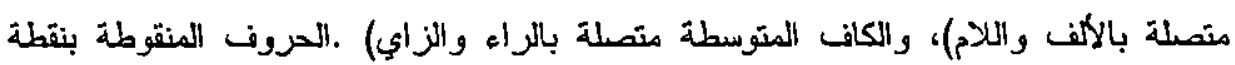

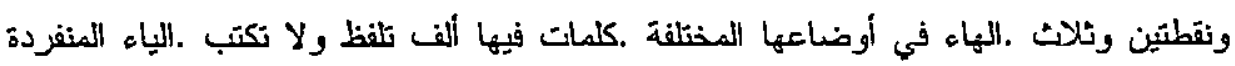
بالألف في أول الكلمة ووسطها .التاء المربوطة المبسوطة .الياء المنفردة بالألف ـ الميم والتاء

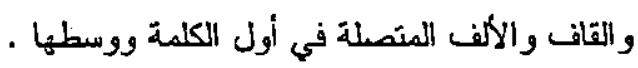

وصف كر اسه الخط للصف البادس :-

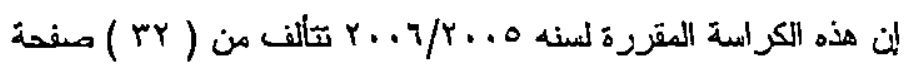

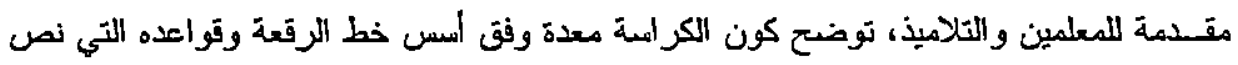

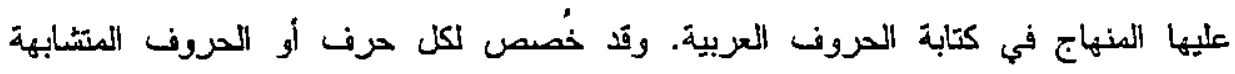
صفحتين : الأولى لتدريب الطلبة على طريقة رسم الحرف وكتابته بصورة صحيحة من خله

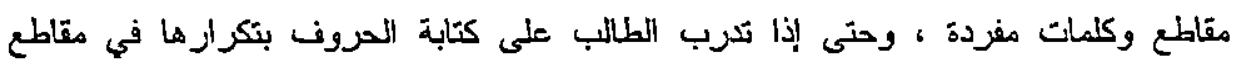

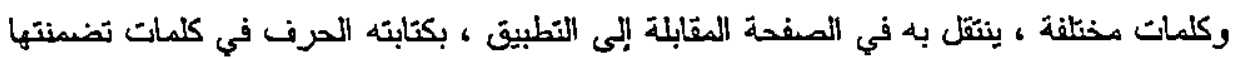

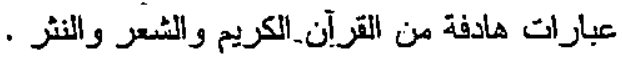


تحديد أهداف تدريس مادة الخط في المرحلة الأساسية :لقد وردت هذه الأهداف ضمن أهداف تدريس مادة اللغة العربية في منهاج المرحلة الأساسية المدية

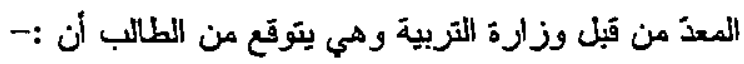

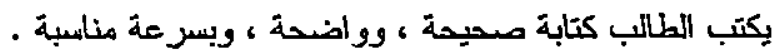

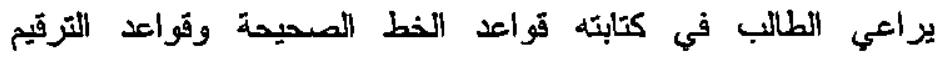
والعلامات المختلفة .

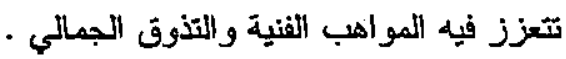
ينمو اعتز ازه بأمته العربية الإسلامية .

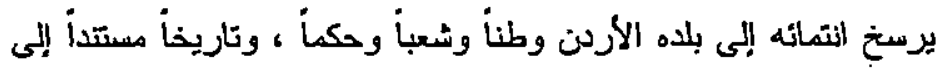

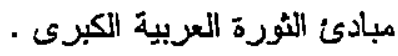

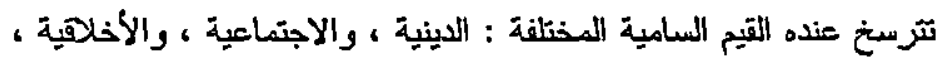
والصحية، و الاقتصادية ، و التاريخية السليمة و العلمية .

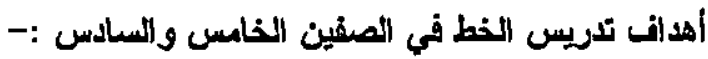

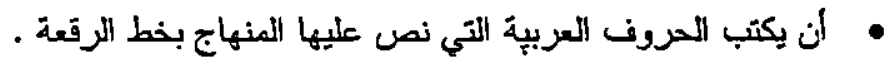

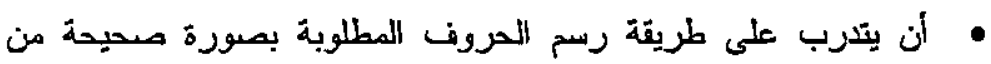
خلا كلمات مجردة . أن يكرر كتابة الحروف في كلمات مختلفة تضمنتها عبارات هادفة من

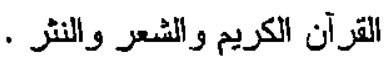
لإن هذا الأجراء ساعد الباحث في الاجابة عن التساؤ لات التالية :-

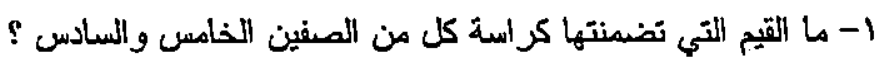

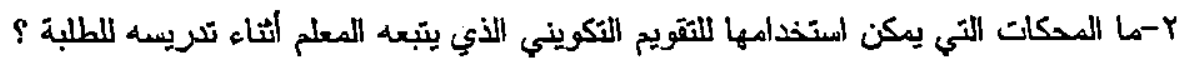
الإجراء الثالث : : وصف كراسة الخط للصف الخامس :-

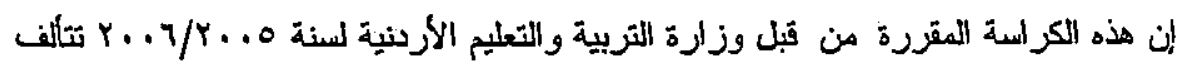
من YV Pفحة :- 
متكاملة ومتفاعلة لتسهيل دراسة الموضوع، وإعطلة صورة واضحة عن مكوناته كما يساعد

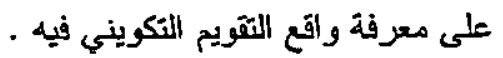

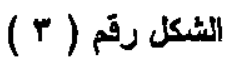

منظومة تقويم واقع ترريس الخط العربي في مرحلة التعليم الأساسية

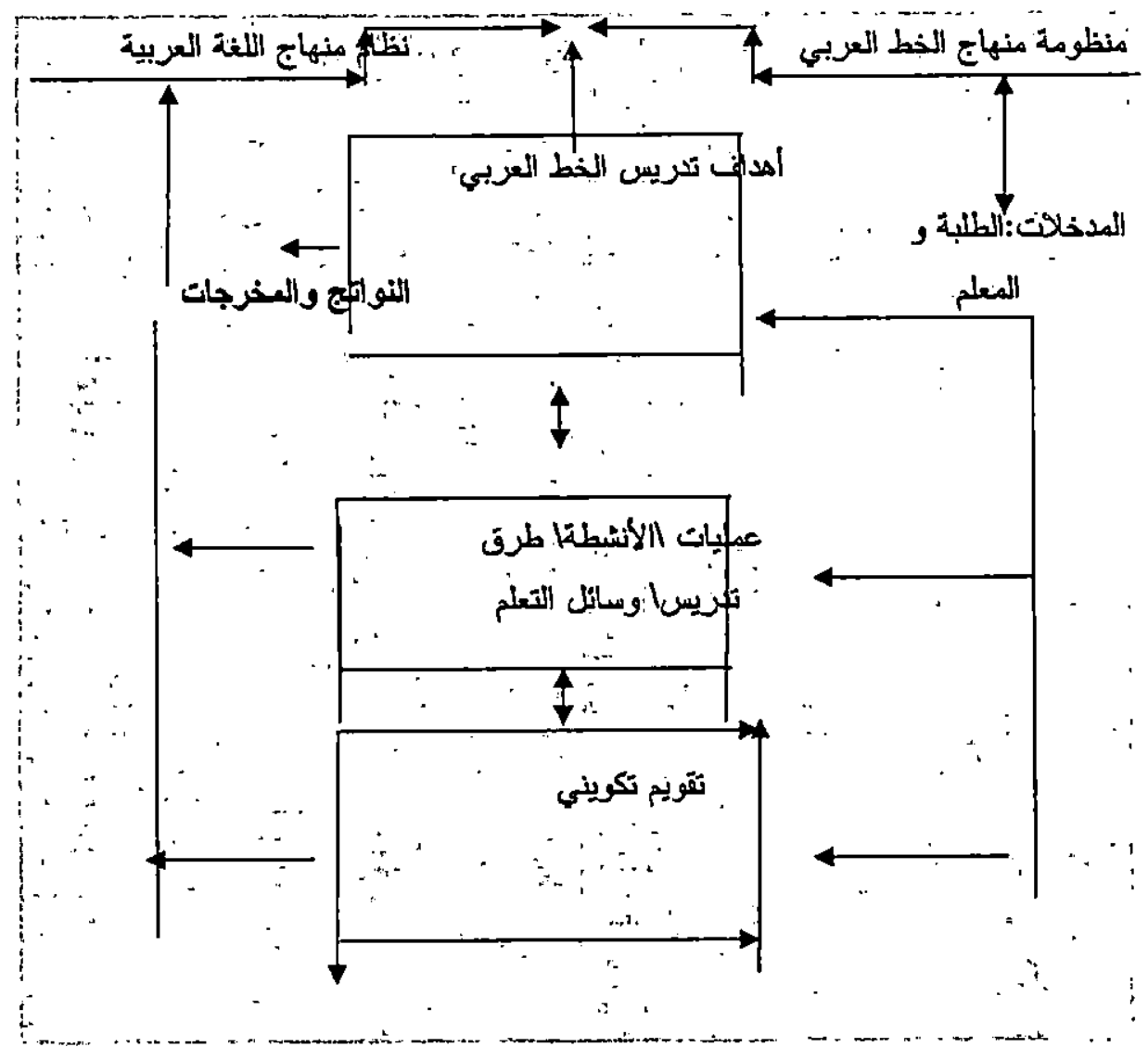


المحنوى :

المحتوى فهو أوسع من المعرفة حيث يُّتل على المعرفة المنظمة وغير المنظمة ، وبالنسبة

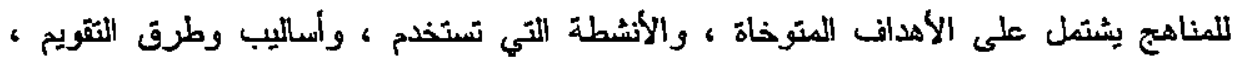

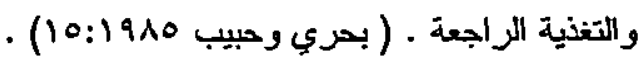

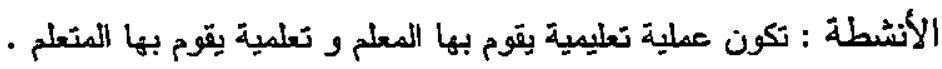
- وتتظم الأشطة بنوعيها لتشكل طرق التعليم ، وهي عامة لكل المواد و المستويات كالمحاضرة

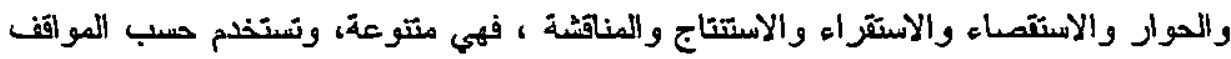

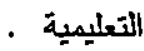

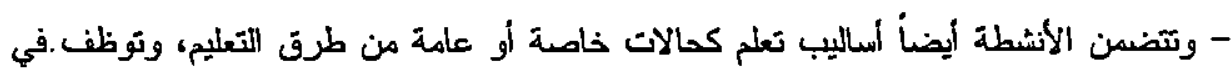

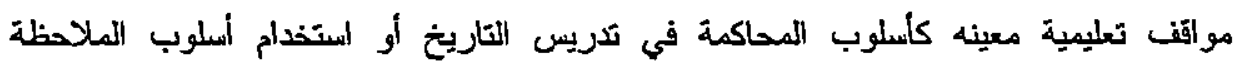
المباشرة في تريس الجغرافية ..وهناك مجال وأسع من تشكيلات الأشطة التعليمية العلمية فئية

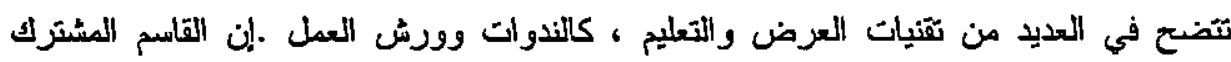

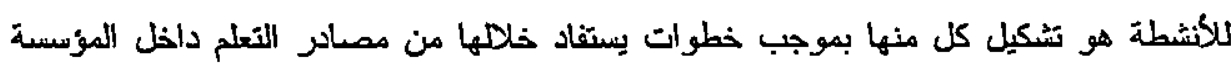

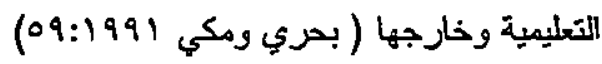
الآقويم :-

يمكن للتقويم أن يأخذ معنى الثقيِيم والتحشخيص بتحديد جوانب القوة والضعف في موضوع

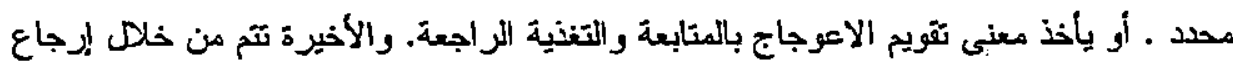
المخرجات إلى المبخلات لتكخل في المنظومة من جديد .ويكون التقويم تكوينياً ، درحلياً ، نامياً

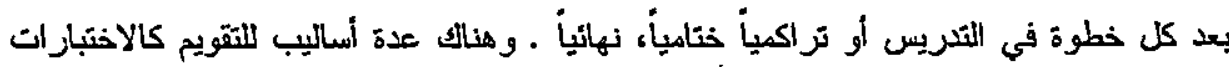

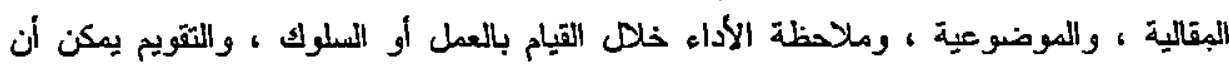

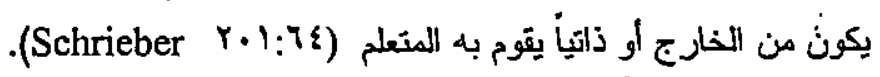

ويرى الباحث أن ما ذُكر عن عناصر النظام يتعلق بالمنهاج المقرر من قبل المؤسسة التعليمية ،

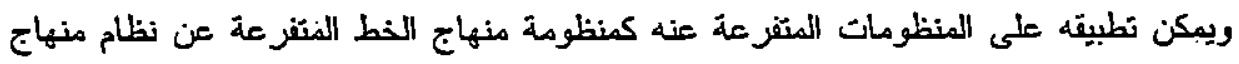

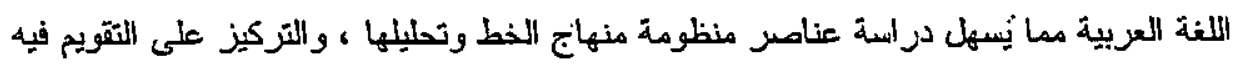
التطويره . ويوضح الثُكل رقت ( r) الأنموذج الذي خرج به الباحث هما ذكر عن النظام لمكونات منظومة تدريس مادة الخط العربي للمرحلة الأساسية حيث يمكن اعتمادها كركيزة أو خارطة نظرية 
الأجزة ، وأي تأثير في أحدها ينتقل البى الأخرى ، ومدخلات جسم الإنسان الماء والهواء

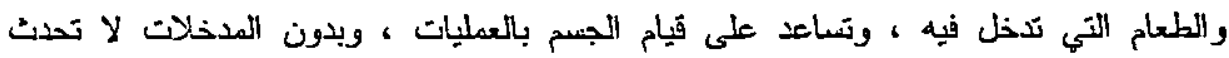
العطليات مما يؤدي إلى الموت ، ومخرجات الإنسان يصعب حصرها ، وهي كل ما يعمله

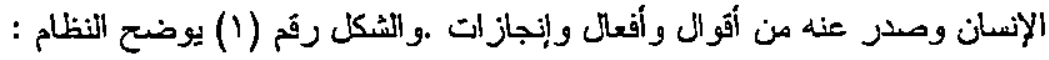

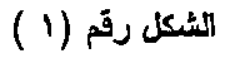

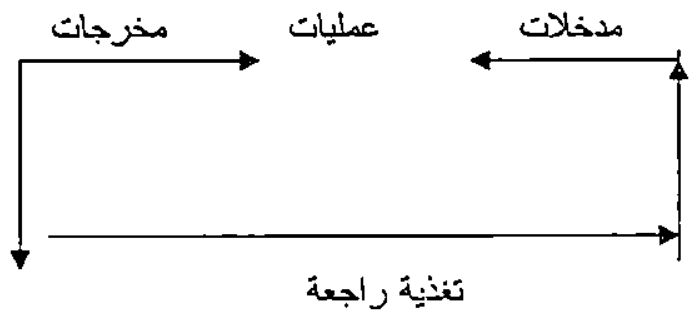

: عناصر المنهج كنظام الأهداف :- (الاهر:

إن للأهداف أهمية بالغة ففي ضونها يتم تحديد المدخلات المطلوب توفيرها ، ويتم تحديد

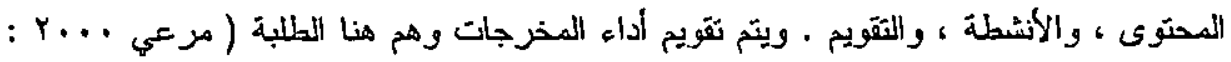

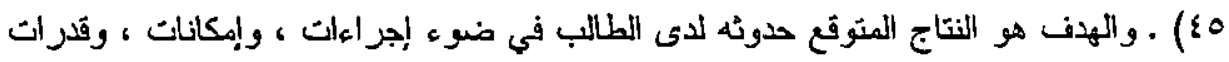

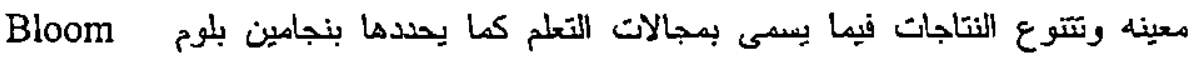

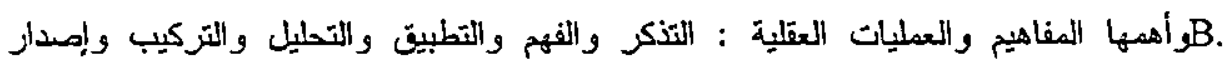

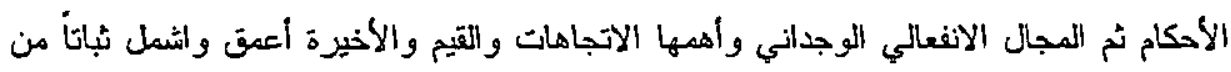

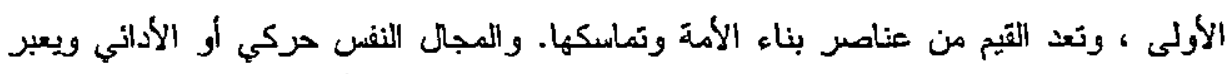

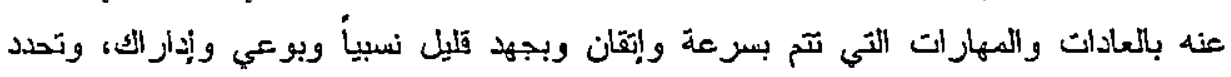

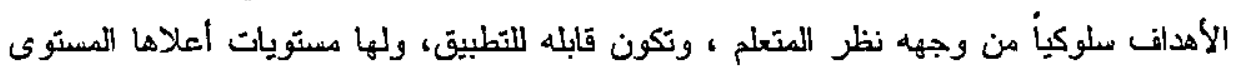

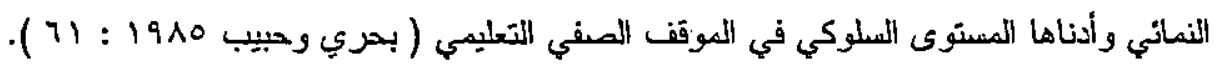


ترتبط بهذه الأهداف فستعرض لاحقأ وحيث بمكن الإفادة منها ـ وأن تحديد مستويات الأهداف يساعد على تحديد محكات التقويم التكويني للخط. o مرض العنصر الثاني في المنظومة : المحتوى : وصف كراسة الخط لكل من المفين الخامس والسادس - صف العنصر الثالث في المنظومة : أنشطة تدريس الخط : الطريقة والوسائل التعليمية المستخدمة كما وردت في المنهاج

$$
\text { المقرر للخط في المنظومة . }
$$

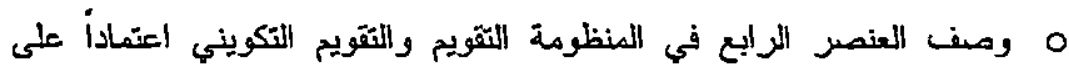

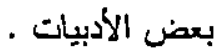

دراسية واقع التقويم التكويني الذي اتبعه المعلم في الخط بموجب إجراءات محددة:

م تحديد العينة

م ت تحديد الأداة والوسائل الحسابية .

م القيام بتحطيل استطلاعي لنسبة من العينة .

o التحقت من صدق وثبات التحليل .

م القيام بتحليل الكراسات ، واستخلاص النتائج في الكشف عن أنماط ومحكات التقويم التكويني، وعن القيم و المهارات ، و المعرفة التي يكتسبها الطالب نتيجة استخدام تلاك الأنماط و المحكات.

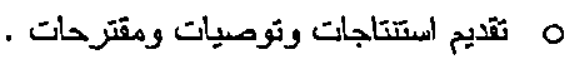
وفيما يلي عرض مفصل لكل إجراء :

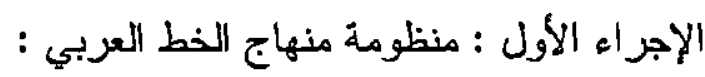

مفهوم النظام : هو الكل المركب من عدد من العناصر، ولكل عنصر وظليفة ، وعلاقات تباصلية ، وأي تأثير في أحد العناصر يُنقل إلى بقية العناصر وللنظام هدف أو أهداف يسعى إلى تحقيقها

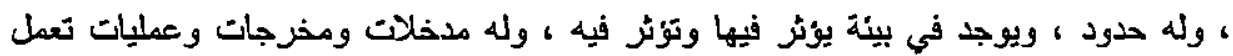

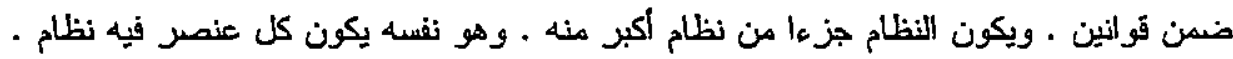

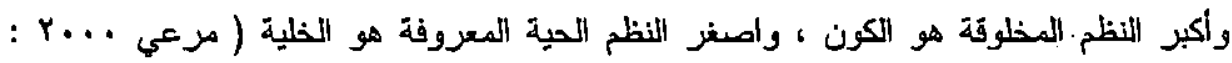
. ( $\leqslant \varepsilon$

ويكون النظام مفنّوحاً إذا تحرلت فيه المدخلات إلىى عليات ، وأعطت المخرجات طبتاً

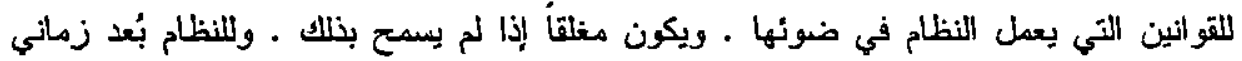

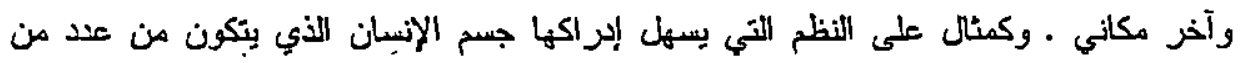


باستخدامه أنماط محدده في التصحيح : علامات ، إبشارات ، عبارات تشجيعية أو توجيهيه وذلك

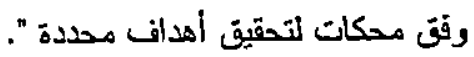
: Handwriting الخط

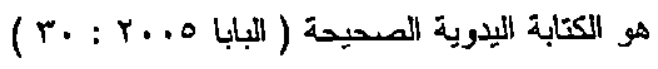

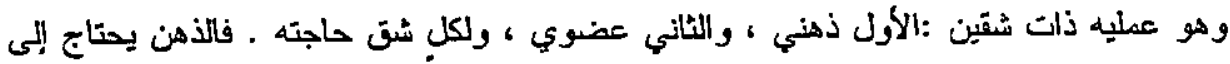

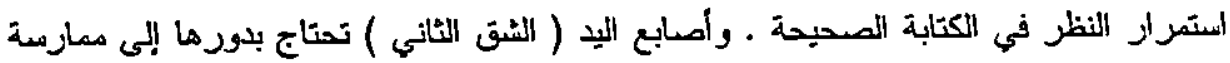
الكتابة الصحيحة باستمر ار ، وهو في مضمونه يساعد على تتميه دهار ات التفكير والموجدان . خط الرقعة : مابهة وهو خط سهل الاستعمال لأن طريقة كتابته خالية من الشكل والزخرفة ، ويعدّ من أيسر أنواع

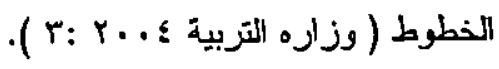
: System النظطام وهو كل مركب من عند من العناصر ، ولكل عنصر وظيفة ، وعلاقات منبادلة وتأثير في بنائه

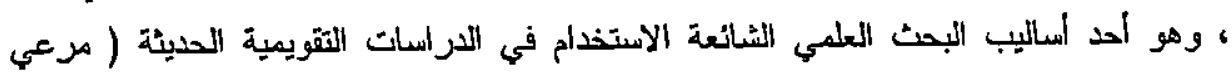
( ) $\varepsilon \varepsilon: Y . \cdots$

\section{: Content Analysis تحليل المحتوى}

هو أداه بحث تستخدم في دراسة وتحليل النصوص المدونة كالكتب الدراسية والمطبوعات

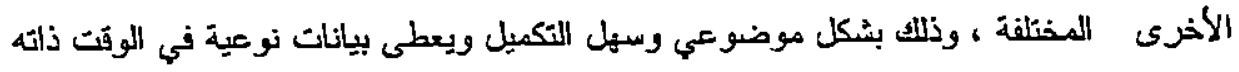
. holistic 1979:91

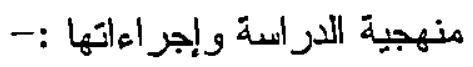

استخدام الباحث المنهج الوصفي التحليلي للمعلومات والبيانات المتيسرة والمتعلقة بالظاهرة قيد

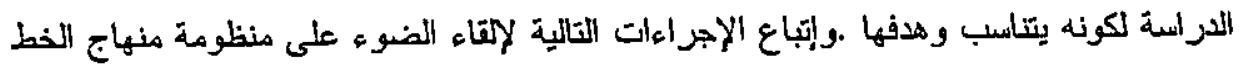
العربي في الصفوف الأساسية التي شمتها بالاراسة ، وعلى واقع التقويم التكويني للخط فيها:

o استباط منظومة لمنهاج الخط في ضوء الأدبيات المتاحة و التي تثارلت المنهاج

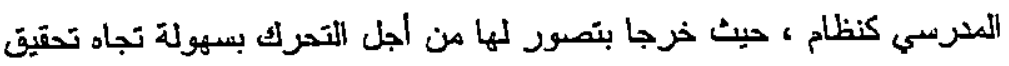
الهذف عبر عناصر المنظومة المتفاعلة .

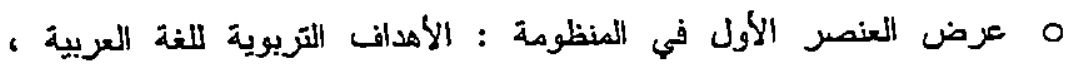

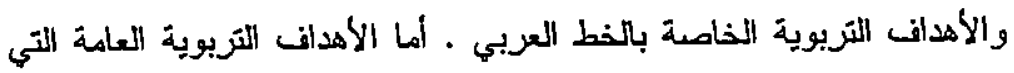


هدفت الدراسة معرفة واقع التقويم التكويني للطلب في منهاج الخط المربي في مرحلة

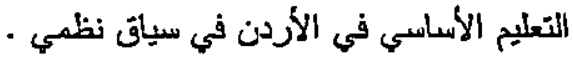

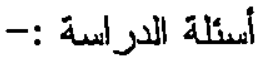

\section{يحاول البحث الاجابة على الأسينة التَالية :-}

1. ها أنماط الثقويم التكويني لخط الطالب في منهاج الخط العزبي المقرر ؟ Y. . ما محكات التقويم التكويني لخط الطالب في المنهاج المقرر ؟ r. ما القيم المتضمنة في محتوى منهاج الخط العربي في ضوء أهدافه التربوية ؟ ع. ما العمليات العقلية والمهارات التي يمكن للطالب أن يكتسبها بموجب أنماط ومحكات

$$
\begin{aligned}
& \text { تقويم خطه ؟ } \\
& \text { محددات الار السة :- } \\
& \text { تحدد الإر المسة بـ :- }
\end{aligned}
$$

• عينه من كراسات الخط العربي المقررة للصفين الخامس والساد من مرحله التعليم

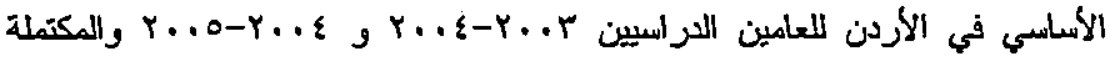
التصحيح وذلك لان طلاب هذين الصفين أكثر نفجا وأعلى مستوى في التحصيل في الخط العبي لذا يفتزض أن تظهر كراساتهم معظم الجوانب التي يسعى التقويم التكويني

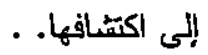

تعينه من طلبه الصفين السادس والسابع الذين تم جمع الكرأسات منهم في مدارسهم. -

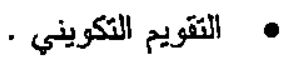$$
\text { • }
$$

تصريف المصطاحسات :-

Evaluation التقويم

يعزفه ( ) في قاموس التربية بأنه عملية التحقق من قيمة الثيء من خلم الإقة في الثقدير

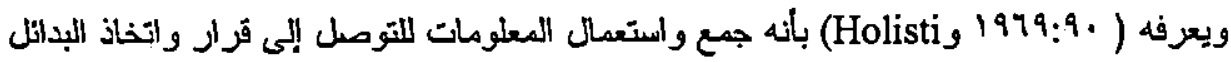
المناسبة ، وهناك نوعان من الثقويم: التكويني (Formative ) ويكون ناميا مستمرا وتصحيحيا بنائيا و النهائه (summative) ويكون ختاميا لمعرفة تأنير برنامج ما في المجموعة الثي الستهدفها .والتقويم التكويني في هذا البحث هو "عملية قيام المعلم بإصدار حكم على قيمة خط الطالب في كراسات الخط المقررة ، وأثناء تصحيحه له في حصة الخط الأسبوعية 
أهمية الدراسةَّة

على الرغم من الجهود التي بذلها الباحث لم يعثر على دراسة لها علاقة مباشرة بموضوع

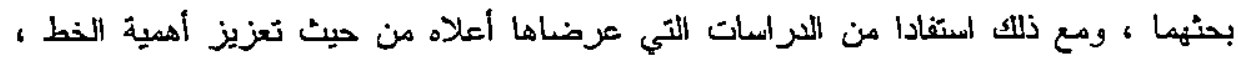
والعوامل البارزة المؤثرة في تعلمه .

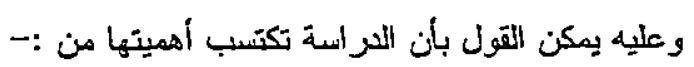

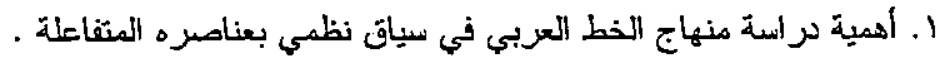

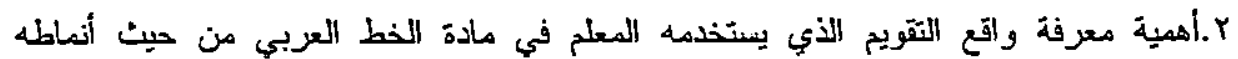

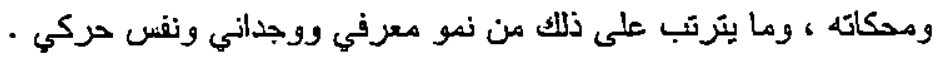

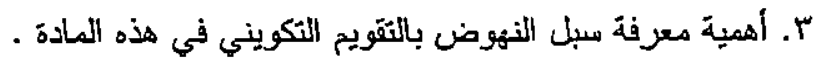

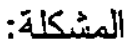

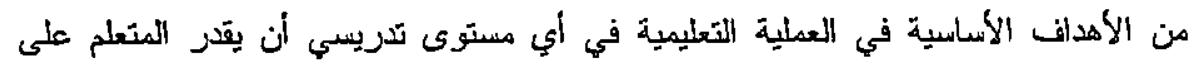

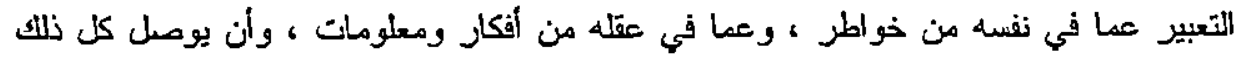

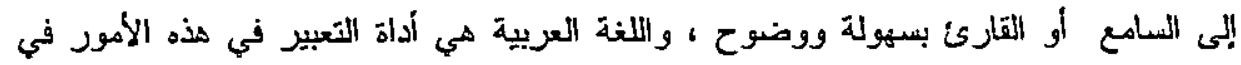

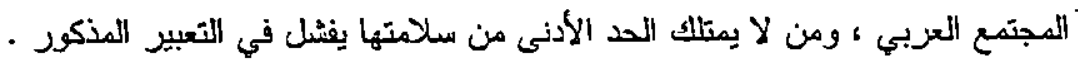

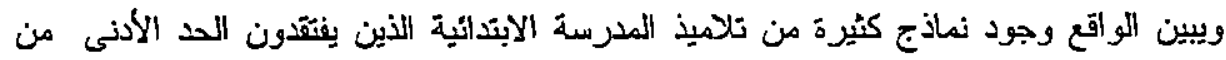

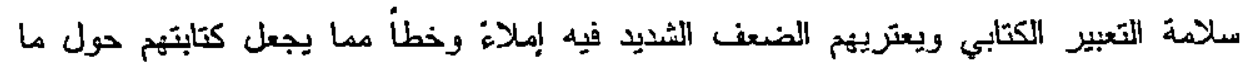
درسؤهِمضطربة ، وغامضنة ، وهذا يؤدي إلى انخفاض مستوى علاماتهم لا في مادة اللغنة

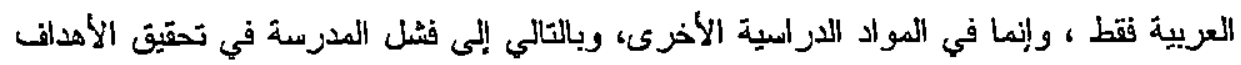

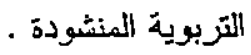

وقد بينت العديد من الدرانعات وجود جملة أسباب لظاهرة ضعف العديد من الطلبة في الخط

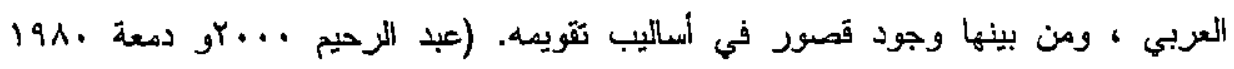

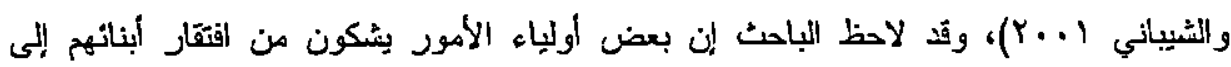

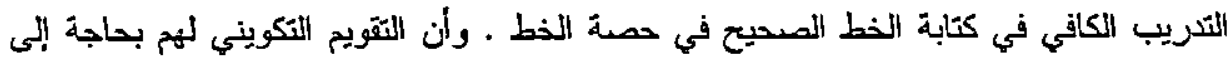

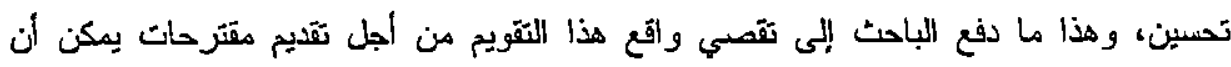

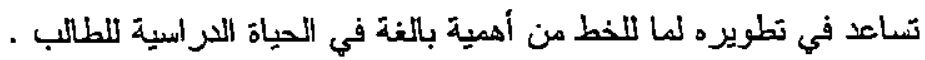

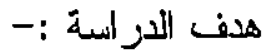


والمعلمات وان (00\% ) منهم يعلمه معلم متخرج من قسم الذط من معاهد الفنون الجميلة وان (

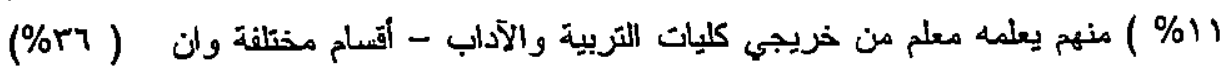
منهم يعلمه معلم من مختلف التخصصات الأخرى لمعاهد المعلمات والمعلمين ، وهذا يعنى أن

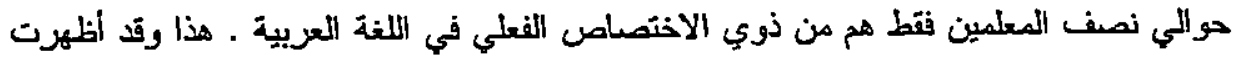

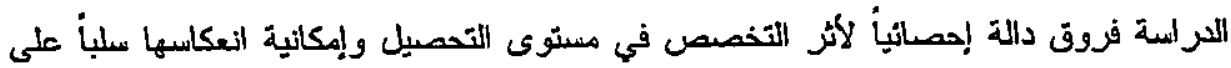
التعبير الكتابي للتلميذ وخطه.

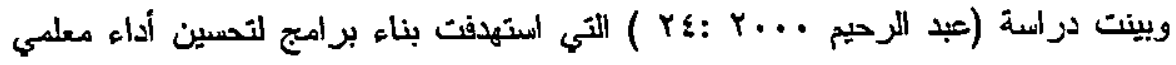

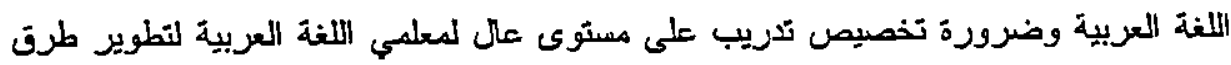

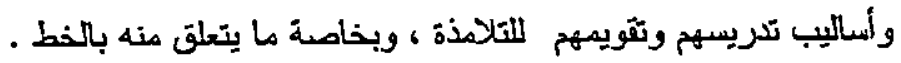

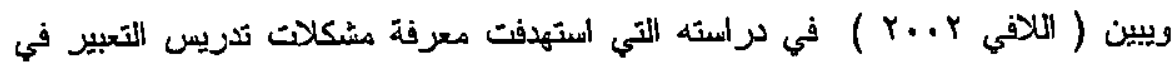

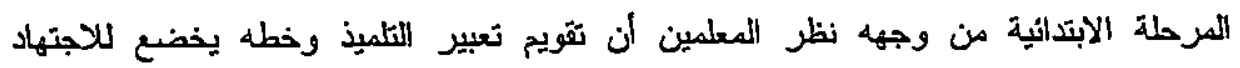

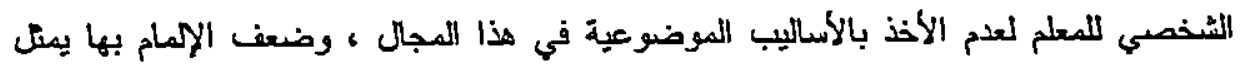
صعوبة قويه تواجه المعلم في تدريس التعبير التحريري. وتوصل و'اطسون (Watson 1999) في دراسته الاتي الستهدفت معرفة مدى الإفادة من

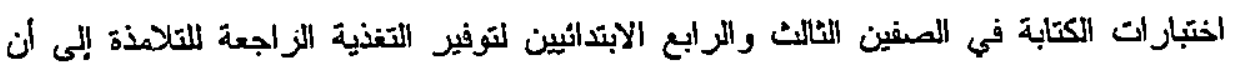

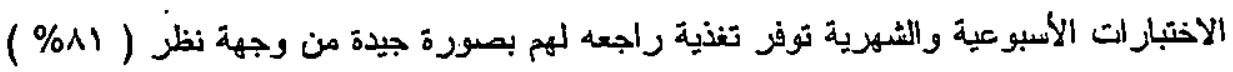

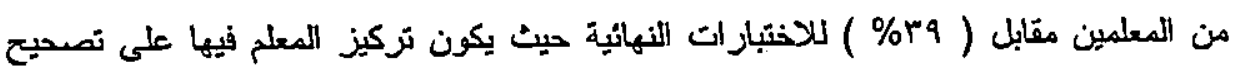

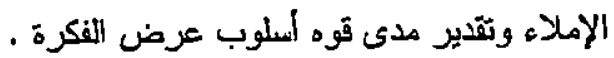

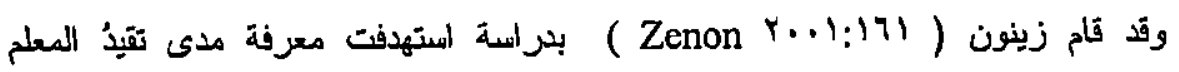
بالتعليمات المتعلقة بقتدير اللرجات المخصصة لكل فرع من فروع اللغة الانجليزية المقررة

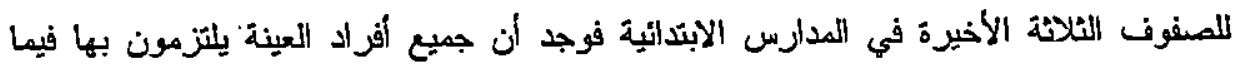

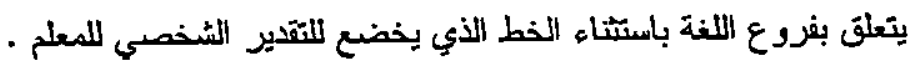

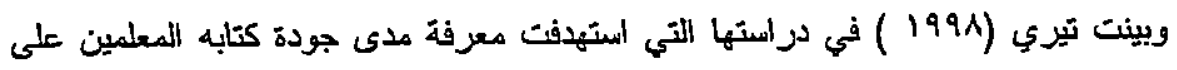

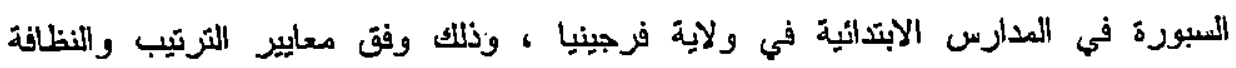

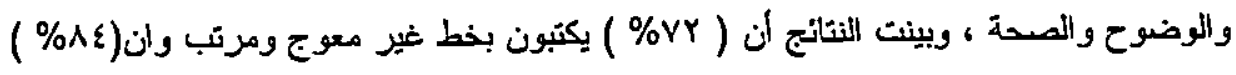
يحرصون على وضوحه وان ( 91\%) منهم لا يخطنون في الكتابة ، وان المعلمين عمومأ

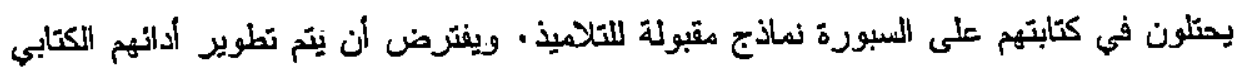

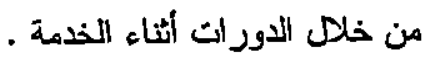


العربية وحده ، بل هي منسؤولية جميع المعلمين باعتبار الخط وسيلة التعبير الكتابي في المواد

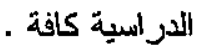

ويشير ( وفق دمعة.19A : IV ) في دراسته التي أستهذفت ثقديم مقترحات لتحسين

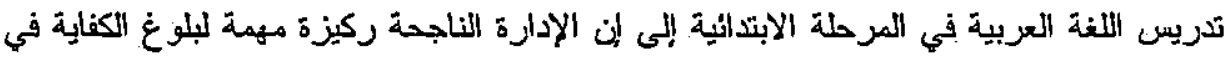
تدريس اللغة العريية ـ فالمدير يجب أن يعتبرها بوابه الثقافة العربية ، وأن يكون الحارس الأنه الأمين الذي يهتم بإعطائها المنزلة اللائقة بها، ومن طرث ذلك تشجيعه للمعلمين على العناية بتكريب

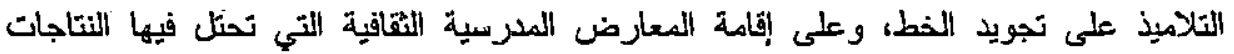
الخطية دساحة ملحوظة. كما يؤكد دمعه على أهمية دور المرشد التزبوي في توجيه المعلم حول خطته في حصة الخط العربي ، وأنماط ثقويمه له فيها.

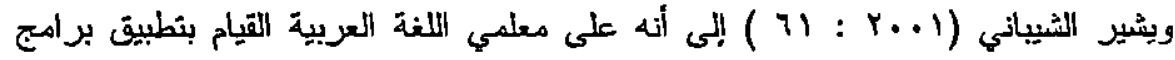
علاجية ، وخطط دراسية دقيقه من أجل تحقيق أهداف تدريس للغة العربية التي من بينها إكساب

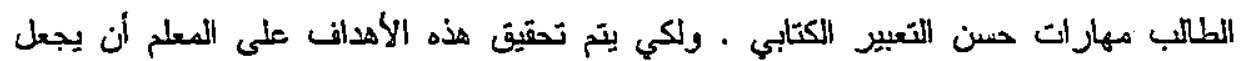

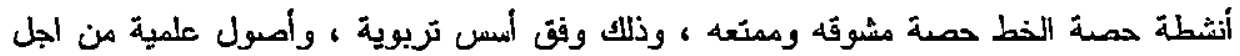

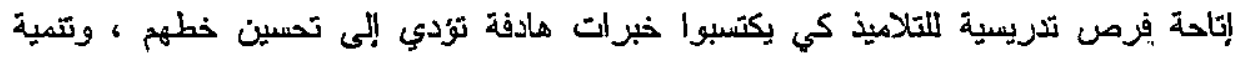

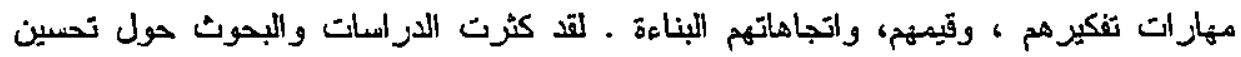
تدريس اللغة العزبية إلا انه من النادر العثور على دراسات تتناول تحسين تدريس الخط العريي عن طريق تثويم اختباز اته.

فقد قامت (بهيجة الحسني 1919 ) ) بدراسة هدفت إلى تشخيص أسباب ضعف تلامذة المدرسة الابتدائية في التعبير الكتابي ، ومما بينته المتائج أن المعاملة الوالديه البييتيه من بين

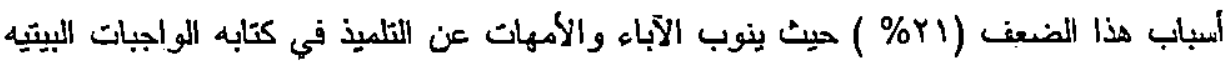
للصغار خشية على أناملهم وأجسادهم الضعيفة من الأزهاق ، ،و العبث بدلأ من مخاطبتهم بلغة

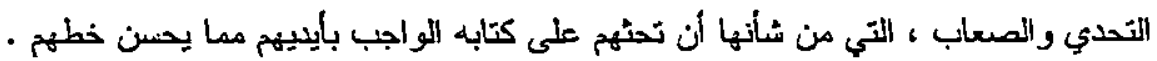

وييين الهاشمي (1999 : 111 ) في دراسته التي الستهوت معرفه تخصصات معلمي اللغنة العربية في المدارس الابتدائية العزاقية وعلاقة ذلك بمستوى تحصيل التثلاميذ في اللغة العربية ومما بينته النتائج أن (\%) (\%) منهم يعلمه معلم صف عربي متخرج من معاهد المعلمين 
إن هذه المكونات كلها تثفاعل فيما بينها وصولاً إلى المخرجات المرجوة ، وأي ضعف فيها

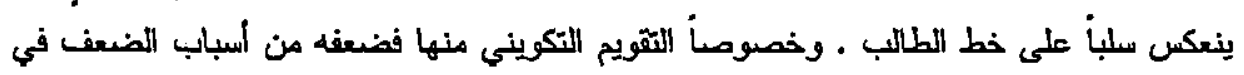

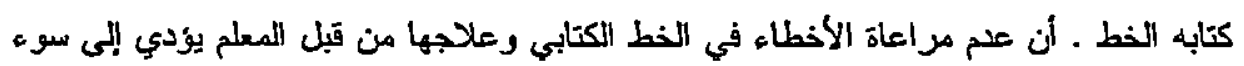

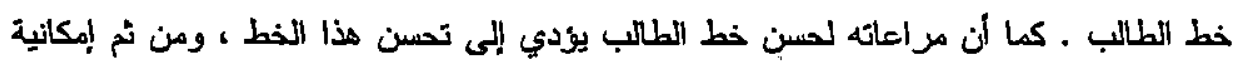

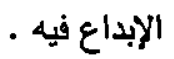

إن دراسة واقع التقويم التكويني الذي يستخدمه المعلم في كراسات الخط المقررة يعكس واقع حال مكونات منظومة منهاج الخط الأخرى ، ويذلك يمكن أن يساعد على تطوير أنليب الثقويم

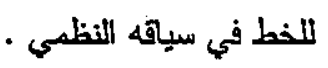

لقد حظي الخط باهتمام واسع وكبير في منل الدراسات التاريخية حيث عولجت مختلف

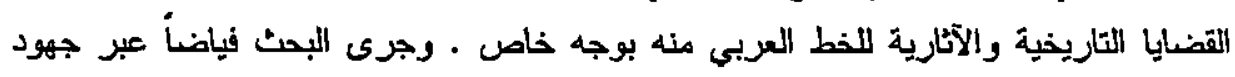

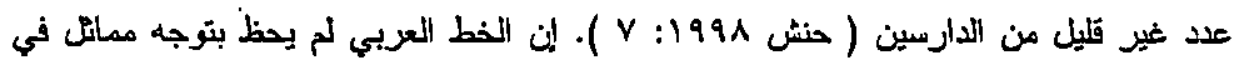

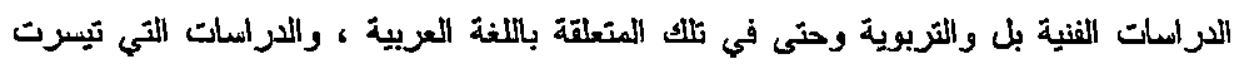

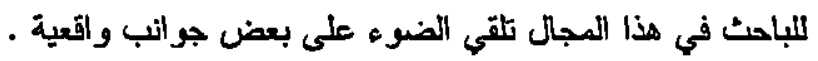

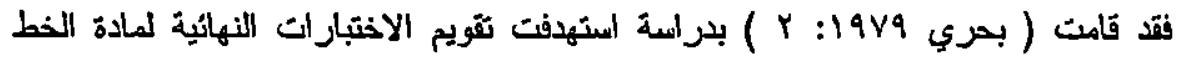

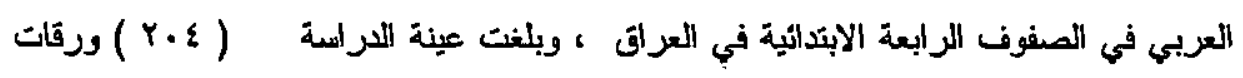

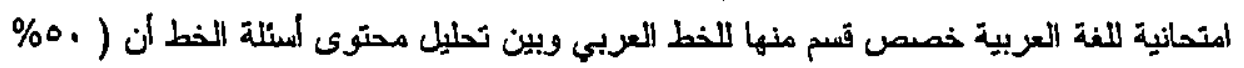

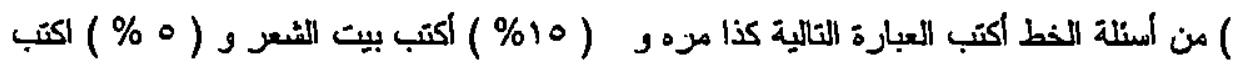

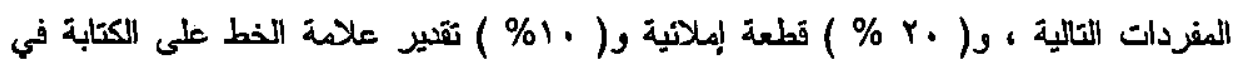

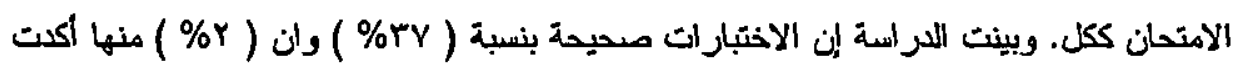

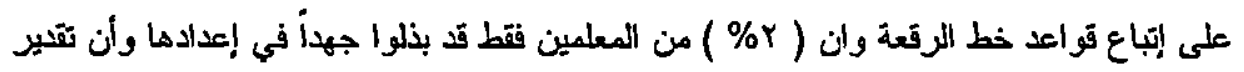

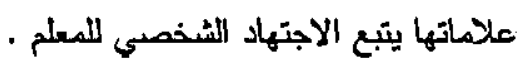

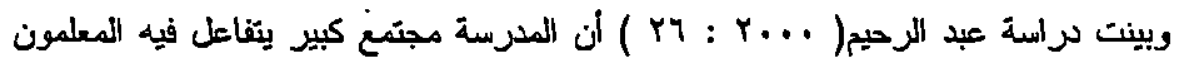

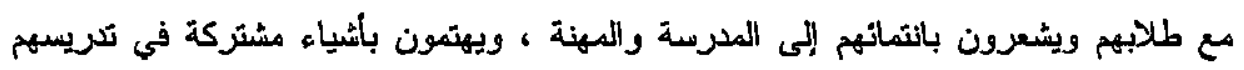
كملاحظة ظاهزة ضعف الخط لاى بعض التلاميذ مما يدفعهم الحوار حول أسبابها ومبل تلافيها

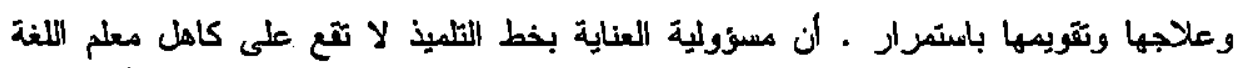


ولصور الخط في كل نوع من الخط نمط معين واستعمالات محدة وتمرص النظم التربوية في

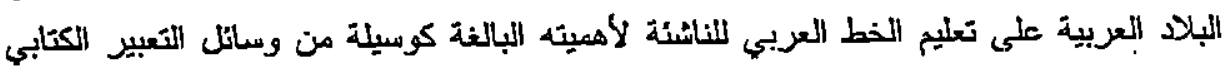

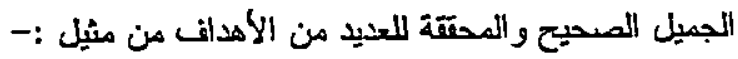

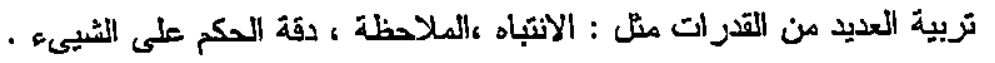

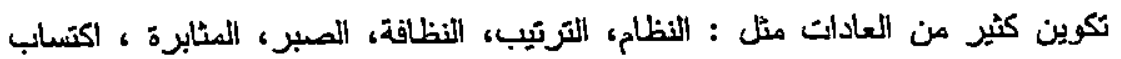
المهارة اليدوية عند التدريب على تجويد الخط .

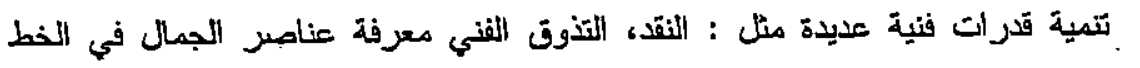
الحسن . اكتساب اتجاهات و القيم مثل :الشعور بالارتياح الثفبه من التقدم في التتريب،، محبة

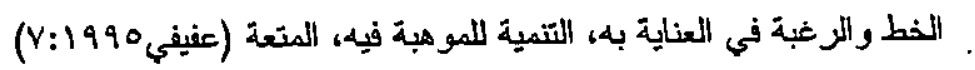

لن معرفة المتعلم بانواع الخطوط المستعملة في المراحل الدراسية وتمكنه منها مهارة أساسية

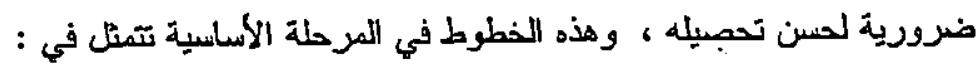
خط النسخ : ( ويستخدم في الصفون الأربعة الأرلي ) وتكتب المصاحف الثريفة، والكتب

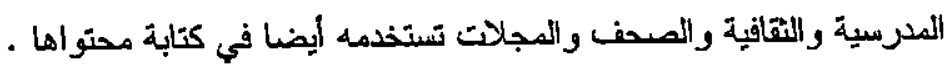
خط الرقعة :(ويستخدم في الصفوف الخامسة والسادسة وما بعدها ) وهو خط الكتابة الاعتيادية

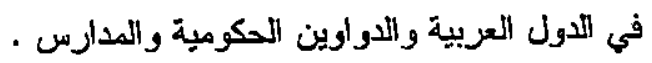

إن تعلم الطالب للخط الصحيح ونمو قدراته فيه يجعل خبراته مغايزة لما كانت عليه سابقاً مما يضفى على عملية تلقي المران والتدريب فيه أهمية كبيرة ، وذللك عن طريت المحارلة والخطا

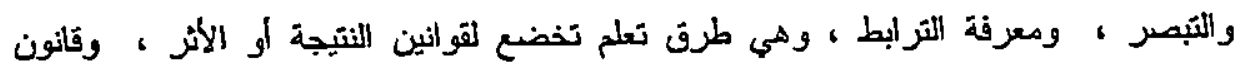

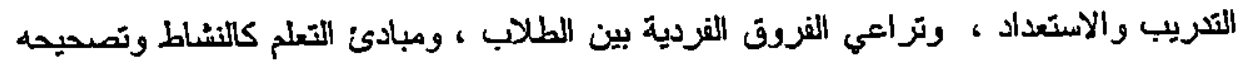

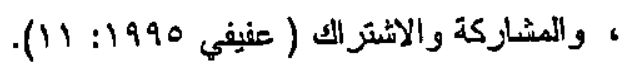

ولأ يخفى ما لطريقة تدريس الخط القائمة على التمهيد وقر اءة النموذج والمشرح الفني واستخدام

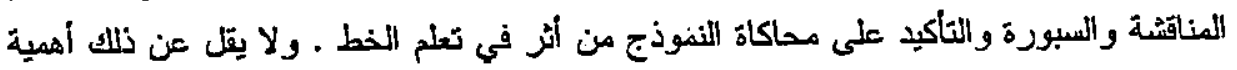

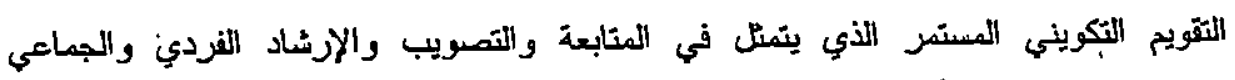

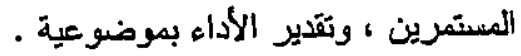




\section{والقّع التقويم التكويني للخط التعريهي في التعطيم الأساسي الأرني في}

\section{سبيلق نظمي}

د. ناصب المخزوفيك'

المقدمة :-

عبر مختلف العصور كانت الكتابة وما تزال ودهما تتوعت أسالييها وسيلة إيلاغ وتفاهم

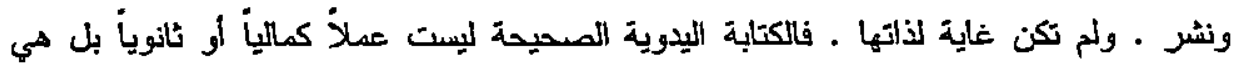

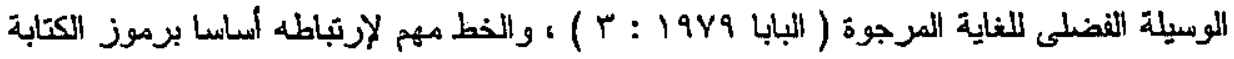

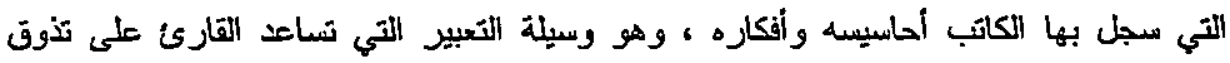

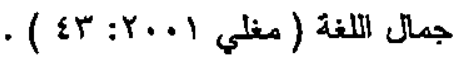

وقد دخل الخط العربي إلى الحجاز من الحيرة في العراق ، وكان يسمى فيها بالخط الحيرى

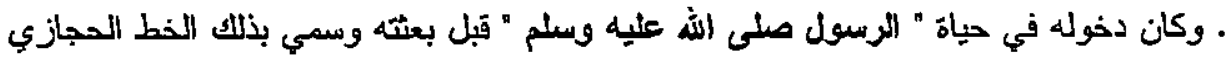

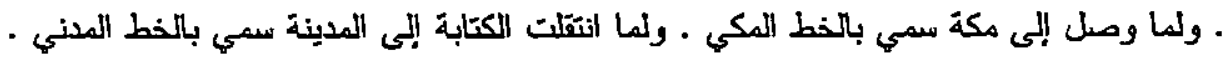

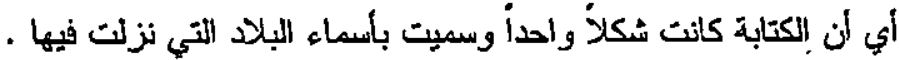

$$
\text { وقد اقتضت ظروف كتابة الموحي أن تدون الكتابة على شكلين : }
$$

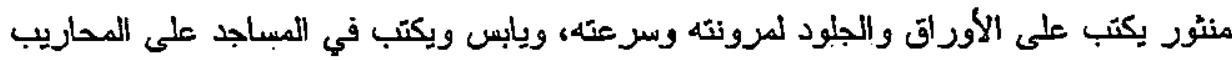
وغيرها لييوسته وكبر حجمه.

ولما وصلت المصاحف في عهد سيلنا عثمان إلى أهصار الشام ومصر والعراق واليمن

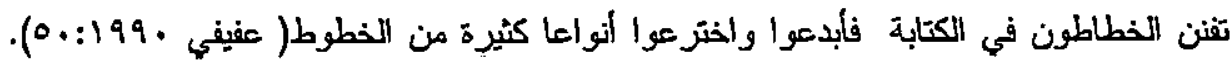

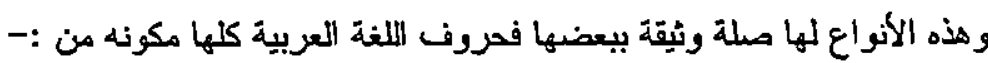

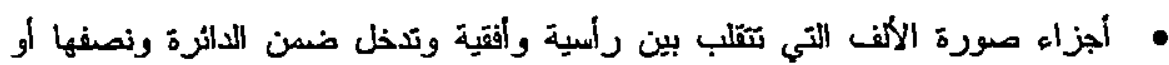
ربعها . • أن هذه الأجزاء بين ماثل ومسطح ومنتصب ومنيلقي .

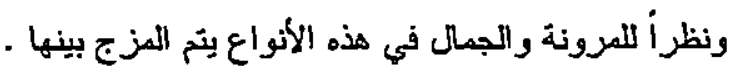
'أمتاذ مشارلك، مناهج وطرق تلريس اللغة العربية، كلية العلوم التربوية، جامعة الزرتاء المناصة 
